\title{
Article
}

\section{Age of the Most Extensive Glaciation in the Alps}

\author{
Catharina Dieleman ${ }^{1, *}$, Marcus Christl ${ }^{2}$, Christof Vockenhuber ${ }^{2}$, Philip Gautschi ${ }^{2}$, Hans Rudolf Graf ${ }^{3}$ \\ and Naki Akçar ${ }^{1}$ (D)
}

1 Institute of Geological Sciences, University of Bern, 3012 Bern, Switzerland; akcar@geo.unibe.ch

2 Laboratory of Ion Beam Physics, ETH Zurich, 8093 Zurich, Switzerland; mchristl@phys.ethz.ch (M.C.); vockenhuber@phys.ethz.ch (C.V.); philipg@phys.ethz.ch (P.G.)

3 Dr. von Moos AG, 8214 Gächlingen, Switzerland; graf@geomv.ch

* Correspondence: catharina.dieleman@geo.unibe.ch

check for updates

Citation: Dieleman, C.; Christl, M.; Vockenhuber, C.; Gautschi, P.;

Graf, H.R.; Akçar, N. Age of the Most

Extensive Glaciation in the Alps.

Geosciences 2022, 12, 39. https://

doi.org/10.3390/geosciences12010039

Academic Editors: Philippe Claeys

and Jesus Martinez-Frias

Received: 17 November 2021

Accepted: 10 January 2022

Published: 13 January 2022

Publisher's Note: MDPI stays neutral with regard to jurisdictional claims in published maps and institutional affiliations.

Copyright: (C) 2022 by the authors. Licensee MDPI, Basel, Switzerland. This article is an open access article distributed under the terms and conditions of the Creative Commons Attribution (CC BY) license (https:// creativecommons.org/licenses/by/ $4.0 /)$.

\begin{abstract}
Previous research suggested that the Alpine glaciers of the Northern Swiss Foreland reached their maximum extensive position during the Middle Pleistocene. Relict tills and glaciofluvial deposits, attributed to the Most Extensive Glaciation (MEG), have been found only beyond the extents of the Last Glacial Maximum (LGM). Traditionally, these sediments have been correlated to the Riss glaciation sensu Penck and Brückner and have been morphostratigraphically classified as the Higher Terrace (HT) deposits. The age of the MEG glaciation was originally proposed to be intermediate to the Brunhes/Matuyama transition (780 ka) and the Marine Isotope Stage 6 (191 ka). In this study, we focused on the glacial deposits in Möhlin (Canton of Aargau, Switzerland), in order to constrain the age of the MEG. The sediments from these deposits were analyzed to determine the provenance and depositional environments. We applied isochron-burial dating, with cosmogenic ${ }^{10} \mathrm{Be}$ and ${ }^{26} \mathrm{Al}$, to the till layer in the Bünten gravel pit near Möhlin. Our results indicate that a glacier of Alpine origin reached its most extensive position during the Middle Pleistocene (500 $\pm 100 \mathrm{ka}$ ). The age of the MEG thus appears to be synchronous with the most extensive glaciations in the northern hemisphere.
\end{abstract}

Keywords: isochron-burial dating; cosmogenic nuclides; Swiss northern Alpine Foreland; Middle Pleistocene; Möhlin glaciation; Bünten Till

\section{Introduction}

The Most Extensive Glaciation (MEG), locally known as Möhlin glaciation, Hosskirch, Mindel, or Most Extensive Helvetic Glaciation (Grösste Helvetische Vergletscherung in German; GHV), is proposed to have occurred during the Middle Pleistocene (774-129 ka; [1]) [2-6]. Previous studies reconstructed its extent by mapping erratic boulders detected beyond the extents of the LGM, along with few relict glacial deposits [5,7,8]. Further, it was suggested that this glaciation reached the interiors of the northern Alpine Foreland and advanced at least until Möhlin (Canton of Aargau), close to Basel in northern Switzerland (Figure 1), where the Rhone, Reuss, Linth, and Rhaetian paleoglaciers coalesced [9-11]. In Möhlin, the Bünten Till, one of the few preserved glacial relicts attributed to the MEG outcrops in a gravel pit. This is perceived to be an important locality for reconstructing the MEG in the Swiss northern Alpine Foreland [3,6,8]. The MEG is also esteemed as the first glacier advance that formed overdeepened valleys in the northern Alpine Foreland [4,12]. Moreover, the MEG was tentatively correlated with the complex of Upper Terraces (HT; Hochterrasse in German) and, therefore, with the Riss glaciation (ca. 130-185 ka) [4,8,9,13], using the four-fold glaciation schemes by Penck and Brückner [9]. Despite several attempts, the exact age of the Alpine glacial expansion still remains a question of debate.

Earlier studies demonstrate that the MEG took place between the Brunhes/Matuyama transition (780 ka) [14] and the Marine Isotope Stage (MIS) 6 (130 ka-191 ka [15]). Based on the morphostratigraphy of the Swiss northern Alpine Foreland, Schlüchter $[2,16]$ proposed that the MEG followed the Deckenschotter glaciations and therefore should have occurred 
just after the Brunhes/Matuyama transition. Analyses of pollen assemblages from the glacial and interglacial sediments of the Lower Aare Valley reveal the MEG to be older than the Holsteinian, an interglacial period generally attributed to MIS 11 (360-420 ka) [4]. In Southern Germany, the Hosskirch glaciation gravel deposits underlie the Holsteinian sediments [5]. According to Keller [6], the MEG is older than the Riss glaciation but younger than the Deckenschotter deposits, thus implying an approximate age of $350 \mathrm{ka}$. The age of the loess layer (19 ka-ca. $60 \mathrm{ka}$ ) overlying the glacial and glaciofluvial sediments in Möhlin, derived from the optically stimulated luminescence (OSL) technique, indicates that the MEG occurred prior to the MIS 6 [17]. U/Th and OSL dating of the Landiswil gravels (Canton of Bern), attributed to the MEG, assigns them an age comparable to MIS 6 [18].

The major objectives of this study were to: (1) put constraints on the age of the MEG in the Alps in context of the northern hemispheric glaciation by focusing on the Bünten Till, which is attributed to the MEG $[3,8,18,19]$ and outcropping in a gravel pit near Möhlin (Figure 1); and (2) reconstruct whether the glacier that deposited the Bünten Till originated from the Alps or the Black Forest. We established the age of the Bünten Till by using isochron-burial dating with cosmogenic ${ }^{10} \mathrm{Be}$ and ${ }^{26} \mathrm{Al}$. The source of the till was determined by analyzing the sedimentology of clasts within the Bünten Till.

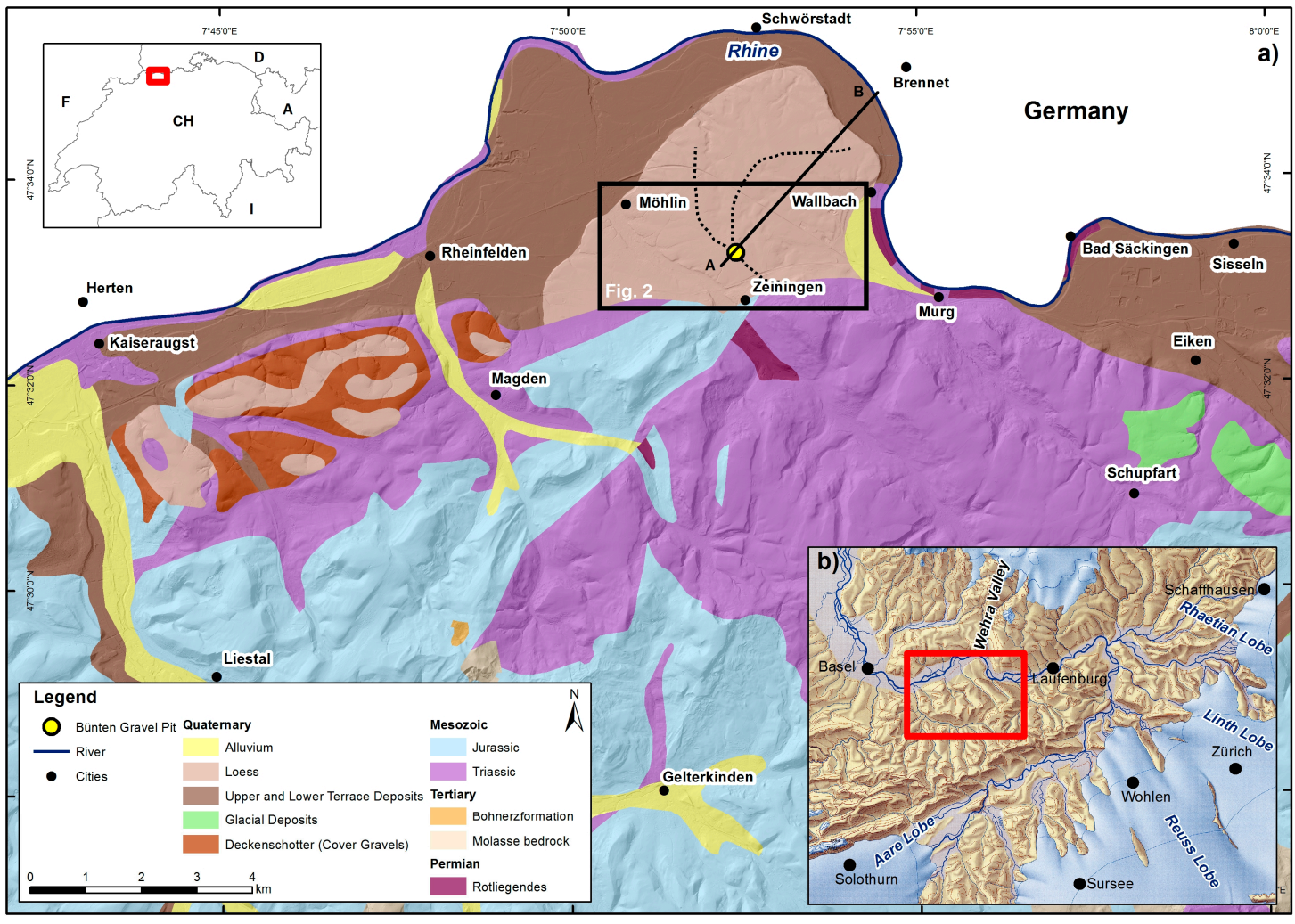

Figure 1. (a) Simplified geological map of the Möhlin area. The black dotted lines indicate the ridges that have been interpreted as moraines by Penck and Brückner [9]. The black rectangle indicates the extent of Figure 2. The cross-section A-B is given in Figure 3. (b) Extent of the Aare, Reuss, Linth, and the Rhaetian Lobes in the Swiss northern Alpine Foreland during the Last Glacial Maximum (LGM) [20]. The background map and the geological 1:500,000 map are reproduced with the authorization of the Swiss Federal Office of Topography (swisstopo). 


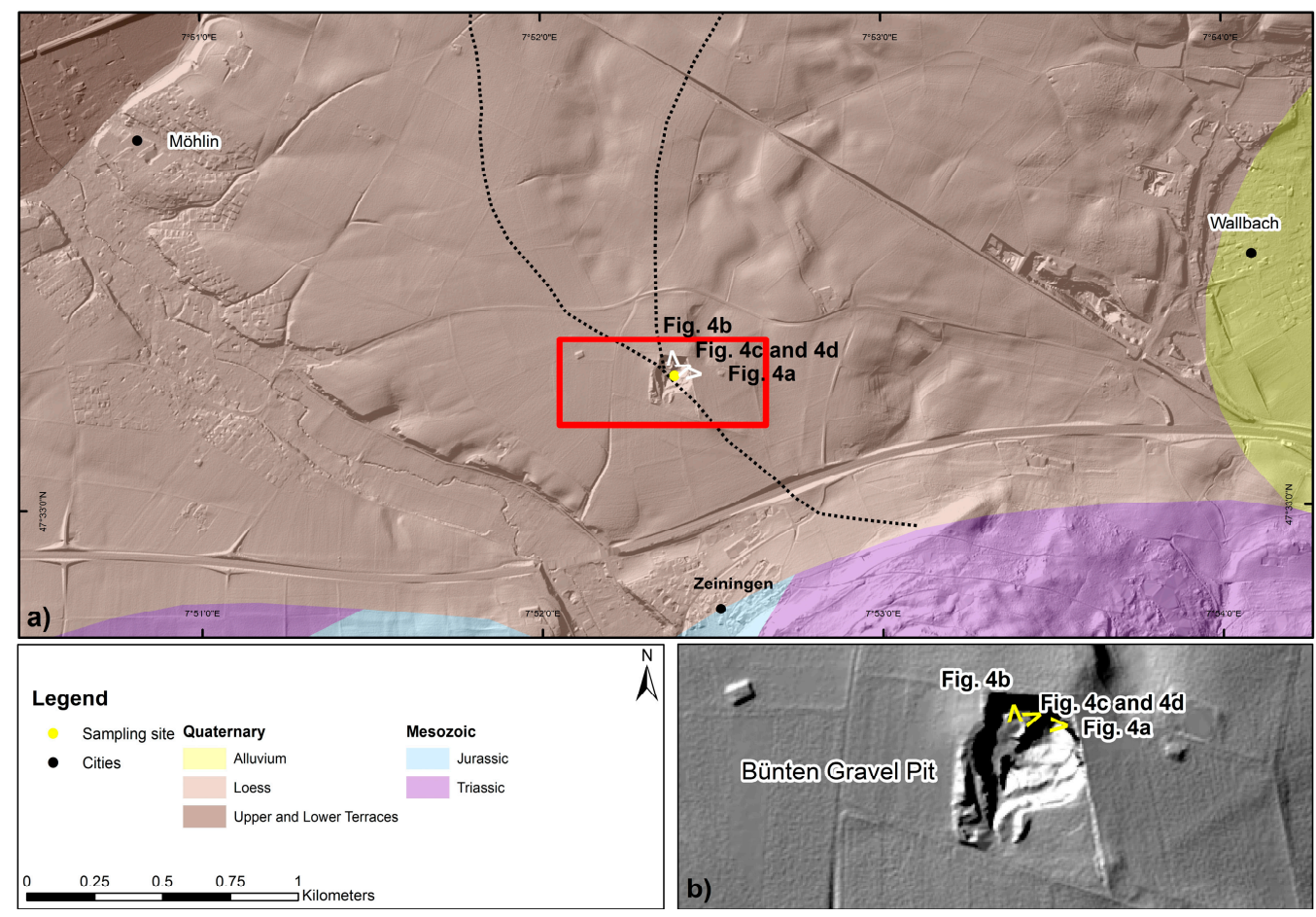

Figure 2. (a) Simplified geological map of the area around the Bünten gravel pit. For its extent, please refer to Figure 1. The yellow dot indicates the sampling site. The white angles in (a) and the yellow ones in (b) display the locations where the pictures in Figure 4 were captured. (b) DEM (Digital Elevation Model) of the Bünten gravel pit. The background map and the geological 1:500,000 map are reproduced with the authorization of the Swiss Federal Office of Topography (swisstopo).

\section{Study Site}

The Bünten gravel pit on the Möhlinerfeld, an approximately $4 \mathrm{~km}$ long and $3.5 \mathrm{~km}$ wide plateau, is located close to Möhlin, approximately $20 \mathrm{~km}$ east of Basel, and to the south of the River Rhine (Figures 1 and 2), with a maximum altitude of $379 \mathrm{~m}$ above mean sea level (m a.s.l.). Permian, Jurassic, and Triassic bedrocks can be observed to have outcropped towards the south of the Möhlinerfeld. HT gravels and Lower Terraces (NT; Niederterrasse in German) have been reported towards the north of the plateau. In addition, the Möhlinerfeld lies far beyond the extents of the Last Glacial Maximum (LGM) (Figure 1). Penck and Brückner [9] have described two shallow ridges of lengths $3 \mathrm{~km}$ and $4 \mathrm{~km}$, respectively, on the plateau, which were previously interpreted as terminal moraines deposited by an Alpine glacier during the Riss glaciation $[9,19]$ (Figures 1 and 2); recent studies have, however, interpreted these ridges as loess rather than terminal moraines $[3,16]$.

The stratigraphy of the Bünten gravel pit has been illustrated in Figure 3a,b $[21,22]$. Although no bedrock is exposed in the gravel pit or has been reached by drilling [22], Müller-Dick [22] has predicted at least a $30 \mathrm{~m}$ thick gravel layer (Figure 3a) overlying the Triassic bedrocks $[9,23]$. The Bünten Till is presently outcropping as a $50 \mathrm{~cm}$ thick reddish till layer containing clasts derived from the Alps and the Black Forest. This layer is not in its original position but is part of a push moraine [23]. The Bünten Till, attributed to the MEG [4], is located approximately $30 \mathrm{~m}$ below the surface, at an elevation of $345 \mathrm{~m}$ a.s.l. [21,22] (Figure 3b). Earlier, the Bünten Till was observed to be located at a lower level of the gravel pit in an autochthonous position, where it is overlain by the glaciofluvial Bünten Gravel. This has later partially been glaciotectonically deformed owing to broken clasts and folding events [21-23] (Figure 3a,b). These gravels predominantly consist of Alpine clasts. However, clasts derived from the Black Forest are also present [4]. The Bünten Gravel is overlain by a paleosol, which is considered to likely represent interglacial climatic conditions [4,21] (Figure 3b). The Wallbach Gravel, located approximately $15 \mathrm{~m}$ 
below the surface, is composed of glaciofluvial gravels of Alpine origin $[4,21]$ (Figure 3a,b). The Bünten and the Wallbach Gravel were together glaciotectonically deformed resulting in a folding of the paleosol. A till layer with sediments derived from the Black Forest envelops the Wallbach Gravel [21]. This entire sequence has been interpreted as the Zeiningen Till [3,4]. Petrographic analyses of this till indicated its deposition by a glacier that originated from the Black Forest [3,4] (Figure 3a,b). The glacier advance depositing the Zeiningen Till has also been suggested to have deformed the underlying sedimentary units [4]. The uppermost unit of the Bünten gravel pit is a $10 \mathrm{~m}$ thick loess layer [3,4,21]. The youngest deposit of the Möhlinerfeld is the Möhlinerfeld Gravels, which partly stem from the Black Forest [3,4] (Figure 3a). These gravels overlie the Wallbach Gravels and the Bünten Gravels in the Möhlinerfeld, but are absent in the Bünten gravel pit [3,4,21].

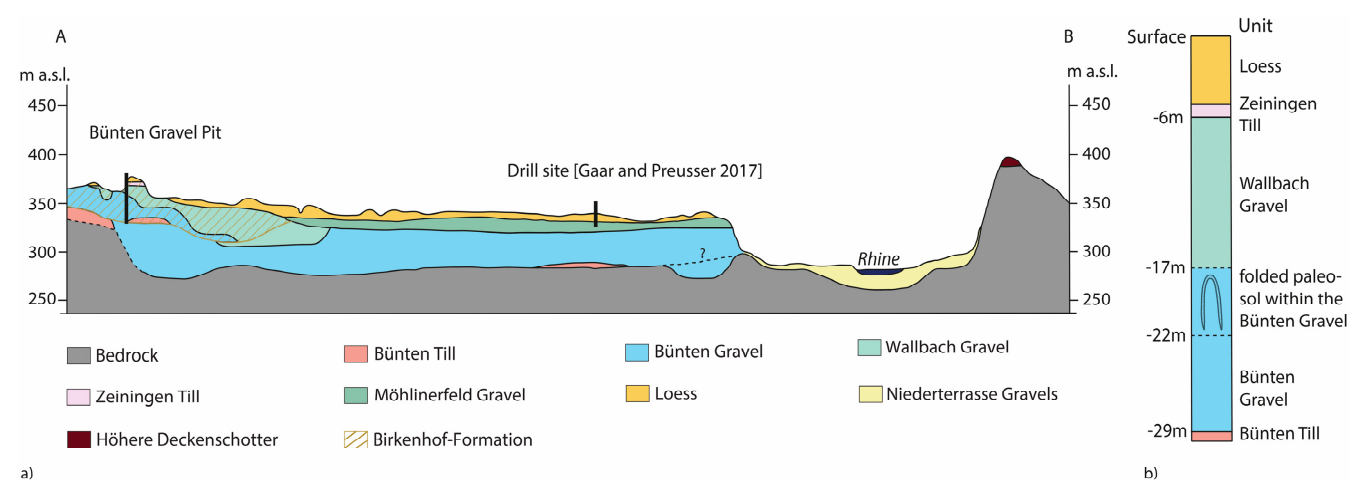

Figure 3. (a) Cross-section A-B showing the different units in the Möhlinerfeld (modified after [23]). (b) Stratigraphic column of the Bünten Gravel Pit (modified after [21]).

\section{Methodology}

\subsection{Sedimentary Analyses}

Petrographic analyses of the clasts provide information regarding the provenance of the sedimentary sequences [24-30]. A sample set of at least 250 clasts was collected from the field utilizing a bucket, to avoid any visual bias [26,30]. The freshly sampled material from the till was sieved into the pebble fraction $(2-6 \mathrm{~cm})$. The clasts were petrographically classified into the following lithology classes: (1) light colored limestone, (2) dark colored limestone, (3) gray colored limestone, (4) sparitic limestone, (5) ocher colored limestone, (6) oosparite, (7) siliceous limestone, (8) vein quartz, (9) quartzite, (10) chert/hornstone, (11) radiolarite, (12) sandstone, and (13) crystallines $[8,25,26,30]$. The crystalline components are utilized to distinguish the Black Forest and the Alpine origin clasts. Red colored granite clasts characterize the Black Forest origin [31], whereas the greenish and white colored crystallines characterize the Alpine origin.

The clast morphometric analysis is a commonly utilized method to distinguish between glacial and fluvial transport mechanisms [32]. Among the several methods developed for these analyses [32-34], we applied the Cailleux method [33], appropriate for glacial and melt water environments [26,33]. As the transport resistance varies with the lithologies, it is essential to analyze clasts from the same lithology [26,32]. The dark colored limestone clasts account for the most abundant lithology and hence 100 such clasts were segregated from the pebble fraction for analytical purposes. Moreover, flattening $\left(A_{i}\right)$ and roundness $\left(\mathrm{Z}_{\mathrm{i}}\right)$ indices for these clasts were determined in the following manner:

$$
\begin{aligned}
& \mathrm{A}_{\mathrm{i}}=\frac{\mathrm{a}+\mathrm{b}}{2 \mathrm{c}} \times 100 \\
& \mathrm{Z}_{\mathrm{i}}=\frac{2 \mathrm{r}_{1}}{\mathrm{a}} \times 1000
\end{aligned}
$$


where $\mathrm{a}$ is the length of the clast, $\mathrm{b}$ the width, $\mathrm{c}$ the thickness, and $\mathrm{r}_{1}$ the radius of the smallest curvature [33,35].

The depositional environment and the transport mechanism were determined by analyzing the clast fabric $[32,34,36-38]$. The clast fabric provides information on the orientation of a single clast, which forms the basis for reconstruction of paleoflow directions $[29,38-40]$. Elongated clasts were examined for this purpose [40]; that is, only the clasts with an a-axis $>6.3 \mathrm{~cm}$ and a:b ratio of $>1.5$. Thus, it was ensured that measurements of elongated clasts were utilized for the paleoflow reconstruction. The orientation and the inclination of 25 clasts fulfilling these criteria were measured in the field.

\subsection{Isochron-Burial Dating}

The isochron-burial dating technique is generally utilized to establish a chronology for $0.1 \mathrm{Ma}$ to $5 \mathrm{Ma}$ old terrestrial deposits such as fluvial terraces, paleosols, and glaciofluvial gravels [30,41-54]. It can be further applied to deposits composed of clasts, with a more complex pre-burial history or which experienced post-burial production $[41,48,51,55]$. The technique is based on the radioactive decay of cosmogenic ${ }^{10} \mathrm{Be}$ and ${ }^{26} \mathrm{Al}$ and uses the difference between the production ratio at the surface at the point of deposition and the measured ${ }^{26} \mathrm{Al} /{ }^{10} \mathrm{Be}$ ratio of the deposit to calculate the depositional age [41,45,47,48,51]. The samples should have different pre-burial histories in order to calculate their isochronburial age; that is, they should differ in the inherited nuclide concentrations. To fulfill this criterion, samples of different lithologies, sizes, and shapes were collected [45-49,51,54].

Sampling, Sample Preparation, and Measurements

A total of 12 samples, 11 clasts (quartzite, sandstone, and granite) and a sediment sample (of 50 small quartz pebbles) were collected from the Bünten Till. The samples for cosmogenic ${ }^{10} \mathrm{Be}$ and ${ }^{26} \mathrm{Al}$ analysis were prepared at the Surface Exposure Laboratory of the University of Bern. The sediment and nine clast samples were leached and purified ([51], and references therein) to obtain $50 \mathrm{~g}$ pure quartz. Ideally, Al concentrations $<30 \mathrm{ppm}$ are required for high quality ${ }^{26} \mathrm{Al} /{ }^{27} \mathrm{Al}$ Accelerator Mass Spectrometry (AMS) analysis $[51,54]$. However, the new AMS facility (MILEA), recently developed at ETH Zurich, measures ${ }^{10} \mathrm{Be}$ and ${ }^{26} \mathrm{Al}$ with higher efficiency [56], allowing us to use samples with higher total $\mathrm{Al}$ concentrations ( $>100 \mathrm{ppm}$ ). Before dissolving, the total $\mathrm{Al}$ concentrations of the samples were checked utilizing inductively coupled plasma optical emission spectrometry (ICP-OES) at the Institute of Geological Sciences, University of Bern. In addition, samples with extremely high total Al concentrations ( $>100 \mathrm{ppm}$ ) were subjected to additional leaching steps or were abandoned. Six samples with lowest total Al concentrations and a sufficient amount of pure quartz were dissolved (Table 1). A full process ${ }^{10}$ Be blank was processed in a batch of nine samples. Samples were spiked with $200 \mu \mathrm{L}$ and the full ${ }^{10}$ Be process blank with $400 \mu \mathrm{L}$ of $1 \mathrm{~g} / \mathrm{L}{ }^{9} \mathrm{Be}$ carrier. The cosmogenic ${ }^{10} \mathrm{Be}$ and ${ }^{26} \mathrm{Al}$ was extracted following the protocol by Akçar et al. [51]. The ${ }^{10} \mathrm{Be} /{ }^{9} \mathrm{Be}$ and the ${ }^{26} \mathrm{Al} /{ }^{27} \mathrm{Al}$ ratios were measured in the MILEA AMS facility at ETH Zurich [57,58]. An error weighted average full process blank ratio of $(2.76 \pm 0.18) \times 10^{-15}$ was utilized to correct the measured ${ }^{10} \mathrm{Be} /{ }^{9} \mathrm{Be}$ ratios. ICP-OES, at the Institute of Geological Sciences, University of Bern, was utilized to determine the total Al concentrations. The CRONUSEarth exposure age calculator was utilized to calculate the ${ }^{26} \mathrm{Al} /{ }^{10} \mathrm{Be}$ ratios, which were referenced to 07KNSTD ([59] and the updates from v. 2.2 to v. 2.3 published by Balco in June 2016; http://hess.ess.washington.edu/math/al_be_v23/al_be_multiple_v23.html; accessed on 13 January 2021). The isochron-burial ages were calculated with the MatLab ${ }^{\circledR}$ code provided by ([45]; personal communication with Darryl Granger) considering $1 \sigma$ measurement uncertainties. To calculate an isochron-burial age, we applied a production rate of $4.00 \pm 0.32$ atoms $/ \mathrm{gSiO}_{2} / \mathrm{a}$ cosmogenic ${ }^{10} \mathrm{Be}$ at the surface, due to spallation at sea level high latitude (SLHL) [60]. In addition, a surface production ratio of 6.75 was applied for the ${ }^{26} \mathrm{Al} /{ }^{10} \mathrm{Be}$ ratio [41]. The time dependent Lm scheme [61,62] was utilized to calculate the altitude/latitude scaling of the surface production rate. Half-lives of $1.387 \mathrm{Ma}$ 
for ${ }^{10} \mathrm{Be}[63,64]$ and $0.705 \mathrm{Ma}$ for ${ }^{26} \mathrm{Al}[65,66]$ were used. For the determination of an isochron-burial age, initially measured ${ }^{26} \mathrm{Al}$ concentrations were plotted against the measured ${ }^{10} \mathrm{Be}$ concentrations. Furthermore, a regression was calculated through the measured ${ }^{10} \mathrm{Be}$ and ${ }^{26} \mathrm{Al}$ concentrations. Subsequently, the slope of the regressed line was utilized to estimate an initial isochron-burial age based on the offset from the initial surface production ratio [41,45]. Based on this initial age estimate, the post-burial production component is determined, subtracted from the measured concentrations and the resulting inherited concentrations are corrected for isotope decay [41,45]. After determining the pre-burial erosion rates based on the corrected inherited ${ }^{10} \mathrm{Be}$ concentrations, an inherited ${ }^{26} \mathrm{Al} /{ }^{10} \mathrm{Be}$ ratio was calculated [45]. The inherited isotope ratios were applied to estimate a linearization factor, which was applied to correct for post-burial production [45]. The corrected ${ }^{10} \mathrm{Be}$ and ${ }^{26} \mathrm{Al}$ concentrations were again plotted against each other. Finally, these steps have been iterated until age convergence [41,45]. For fluvial depositional environments, the initial ratio equals the surface production ratio, as fluvial clasts are assumed to stem from the surface. Therefore, the surface production ratio of 6.75 [41] is commonly utilized as the initial ratio in calculating isochron-burial ages. This technique has often been applied for determining the age of fluvial terraces (e.g., [43], among others). In landscapes sculptured repeatedly by deep erosion, such as glacial landscapes, the production ratio at depth becomes equal to the initial ratio [51]. As muogenic production becomes dominant with depth, the ${ }^{26} \mathrm{Al} /{ }^{10} \mathrm{Be}$ ratio increases. For example, Braucher et al. [67,68] and Margreth et al. [69] reported a value up to 8.3. In the following, we briefly outline how a glacially created, transported, and deposited clast can account for an initial ratio higher than the surface ratio (6.75). During glacial erosion, the clasts are first excavated by the glacier from the bedrock at depth (deep erosion) (cf. Figure 7 in [51]). Subsequently, these clasts are transported either subglacially or englacially, i.e., completely shielded from cosmic rays. Later, they are embedded in a glacial deposit, such as the Bünten till in this study, or in a glaciofluvial deposit. In both cases, such clasts will never be exposed at the surface prior to burial and their initial ratio will be $>6.75$. As one cannot determine the original depth at the source, from which a clast originates, Akçar et al. [51] suggested to use the production ratio at depth (between 6.75 and 8.4, average value is 7.6) for the isochron-burial age calculations for landscapes dominated by deep erosion. In addition, Knudsen et al. [42] applied the P-PINI (Particle Pathway Inversion of Nuclide Inventories) method to model burial ages, utilizing a source to sink approach. Their modelling demonstrated that the majority of initial ${ }^{26} \mathrm{Al} /{ }^{10} \mathrm{Be}$ ratios at the source were larger than 7.2 (cf. Figure 8 in [42]). They concluded that these samples were derived from environments which experienced fast and deep erosion due to glacier activity. Based on these lines of evidence, the isochron-burial age of the Bünten Till was calculated with initial ratios of $6.75,7.6$, and 8.4 , respectively. The isochron-burial age calculated with an initial ratio of 7.6 has been considered in the ensuing discussion.

Table 1. Sample information for the Möhlin site.

\begin{tabular}{cccccc}
\hline Sample Name & Lithology & Weight (g) & a-Axis (cm) & $\begin{array}{c}\text { Amount of Quartz } \\
\text { after Leaching (g) }\end{array}$ & $\begin{array}{c}\text { Al Concentration after } \\
\text { Leaching (ppm) }\end{array}$ \\
\hline MÖHL-1 & Quartzite & 1150 & 12.7 & 34 & 76 \\
MÖHL-4 & Quartzite & 660 & 12.3 & 44 & 161 \\
MÖHL-5 & Quartzite & 800 & 9.3 & 54 & 145 \\
MÖHL-7 & Quartzite & 520 & 8.2 & 36 & 94 \\
MÖHL-10 & Sandstone & 1630 & 15.3 & 46 & 138 \\
${ }^{1}$ MÖHL-12 & Quartz pebbles & 1610 & - & 67 & 49 \\
\hline
\end{tabular}

${ }^{1}$ Sediment sample. Coordinates of the sampling site: $47.5533^{\circ} \mathrm{N}, 7.8716^{\circ} \mathrm{E}, 345 \mathrm{~m}$ a.s.l. 


\section{Results}

\subsection{Sedimentary Analyses}

\subsubsection{Sediments of the Bünten Gravel Pit}

The till in the Bünten gravel pit is located approximately $30 \mathrm{~m}$ below the surface (Figure $4 \mathrm{a}$ ). The $50 \mathrm{~cm}$ thick till layer is observed to be tilted (Figure $4 \mathrm{~b}$ ). The till is poorly sorted, with clast sizes ranging up to $20 \mathrm{~cm}$ (Figure 4c,d). The clasts are matrix supported, consisting of reddish colored clay and silt (Figure $4 \mathrm{c}, \mathrm{d}$ ). Two groups of paleoflow directions were measured, one towards $\mathrm{N}$ and another towards $\mathrm{W}$, resulting in a NW mean paleoflow direction. The Bünten gravels overlying the till are poorly sorted with a maximum clast size of approximately $25 \mathrm{~cm}$. A sandy to silty matrix can be observed. The horizontally bedded glaciofluvial gravels, located to the west of the Bünten Till, are nearly $10 \mathrm{~m}$ thick (Figure $4 \mathrm{~b}$ ). They contain a matrix predominantly composed of sand and minor amounts of silt. A maximum clast size of $25 \mathrm{~cm}$ has been reported from these gravels. At a depth of $10 \mathrm{~m}$ below the surface, the glaciofluvial gravel sequence exhibits cross bedding (Figure 4a).
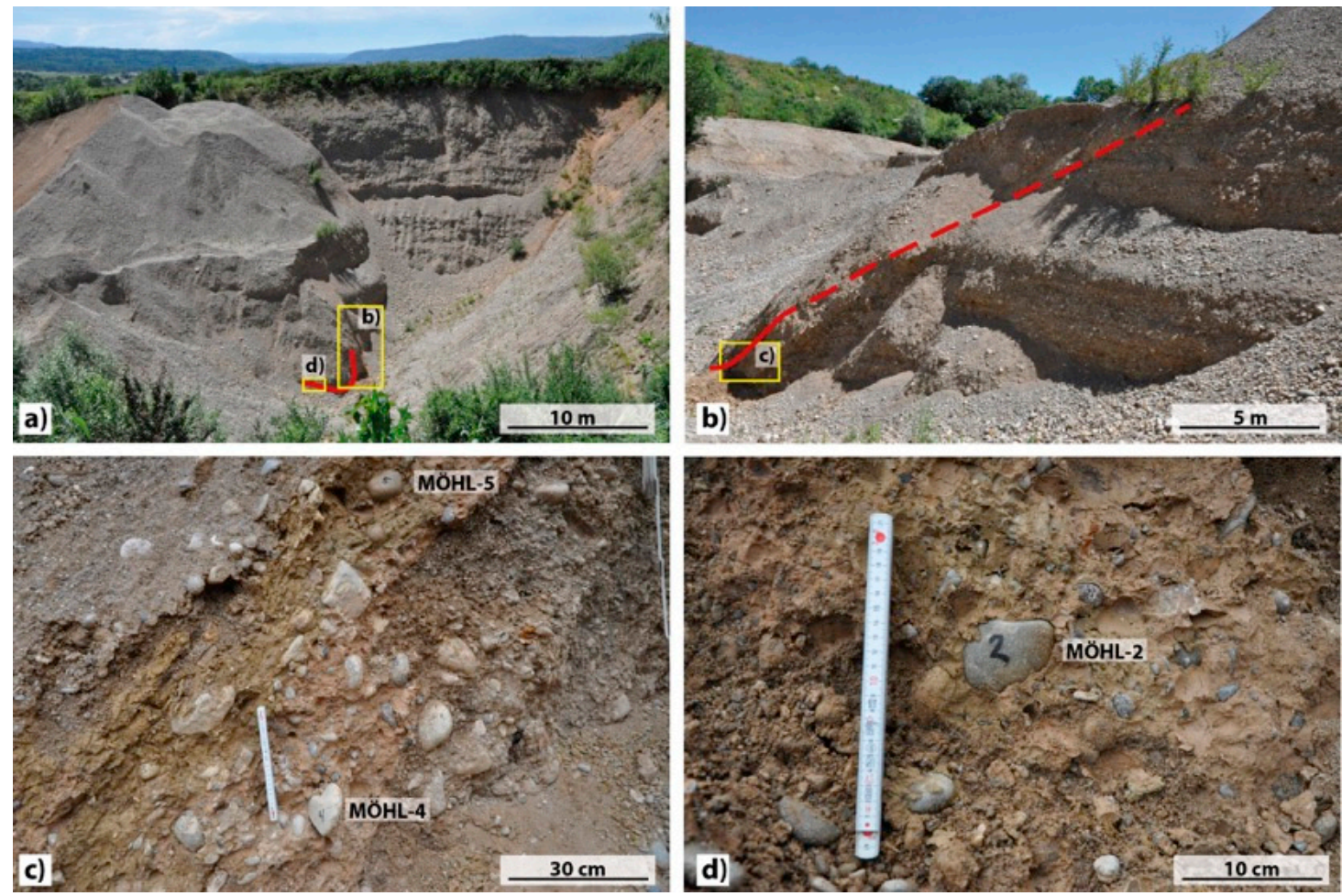

Figure 4. Field photographs of the Möhlin site. (a) Overview of the Bünten gravel pit and spatial positioning of Figure $4 b, d$; (b) the Bünten Till (indicated by the red line) and spatial positioning of Figure 4c; (c) samples MÖHL-4 and MÖHL-5; and (d) sample MÖHL-2.

\subsubsection{Clast Petrography}

The results of the clast petrography for 275 samples are shown in Figure 5. Most of the clasts are dark colored limestones (21\%), successively followed by gray colored limestones $(14 \%)$, quartzites $(13 \%)$, and crystalline clasts $(9 \%)$. The crystalline clasts can be further categorized as those of the Black Forest origin (4\%) and those of the Alpine origin (5\%). The ocher-colored limestones and oosparites account for $8 \%$ and $6 \%$ of the total clasts, respectively. The sparitic and siliceous limestones contain relative abundances of $7 \%$ each. Sandstones, vein quartz clasts, and cherts exhibit a relative abundance of $4 \%$ each. The light colored limestone clasts and the weathered components represent $2 \%$ and $1 \%$ of the total clasts, respectively. Since only one radiolarite clast was found, its abundance was too small to be represented on the pie diagram. 


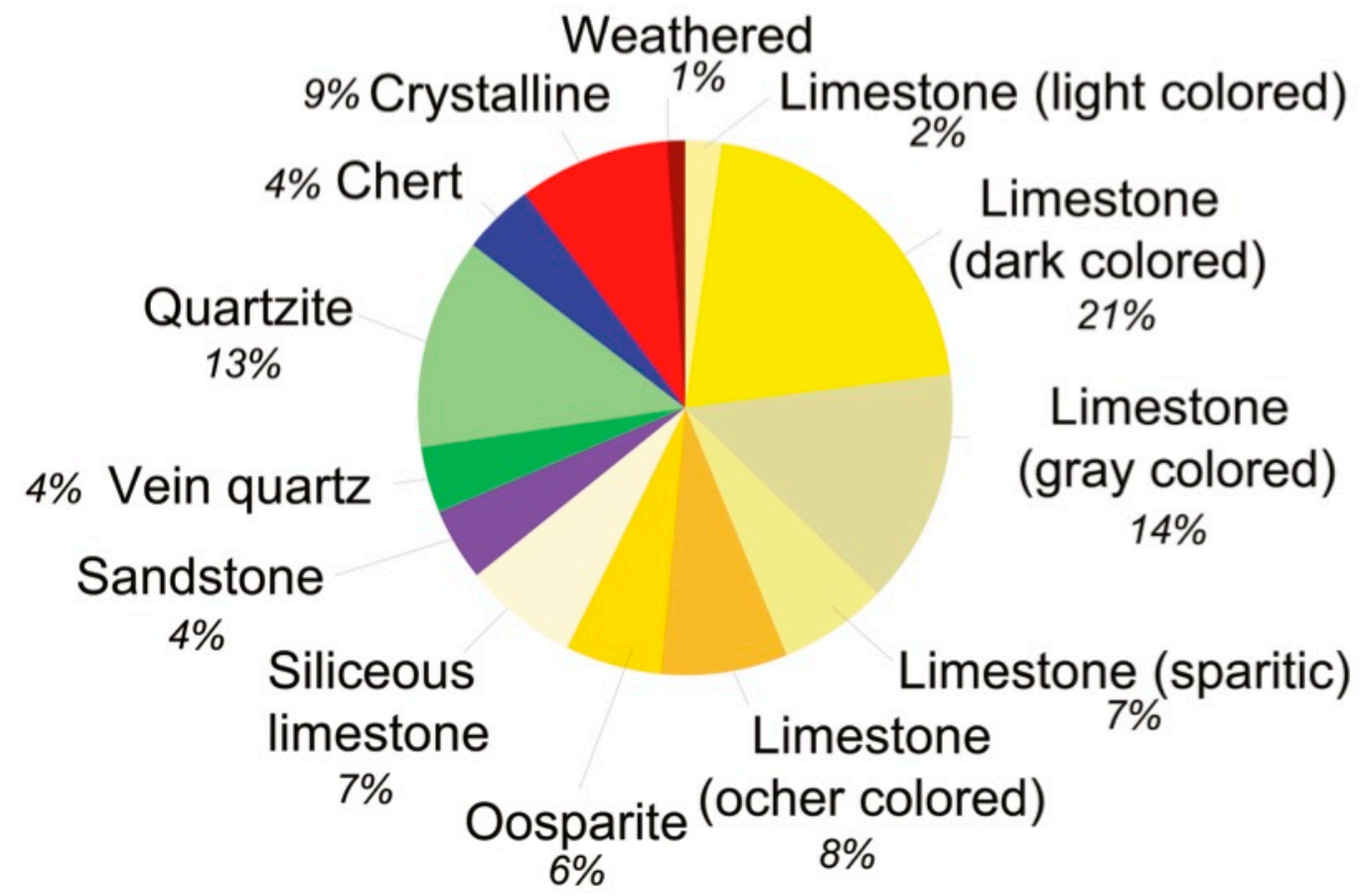

Figure 5. Clast petrography of the Bünten Till analyzed at the Möhlin site.

\subsubsection{Clast Morphometry}

A total of 110 clasts were measured to calculate the roundness index $\left(Z_{i}\right)$ and the flattening index $\left(A_{i}\right)$ (Figures 6 and 7). The $Z_{i}$ values range from 50 to 550 , with a few clasts displaying values between 600 and 700 (Figure 6). The median of the roundness index $\left(\mathrm{Md}\left(\mathrm{Z}_{\mathrm{i}}\right)\right)$ is 244 . The clasts exhibit bimodal distribution, the first highest mode being represented between 100 and 150 and the second between 250 and 300. The calculated flattening indices vary between 100 and 450 with a median $\left(\operatorname{Md}\left(\mathrm{A}_{\mathrm{i}}\right)\right)$ of 180 (Figure 7).

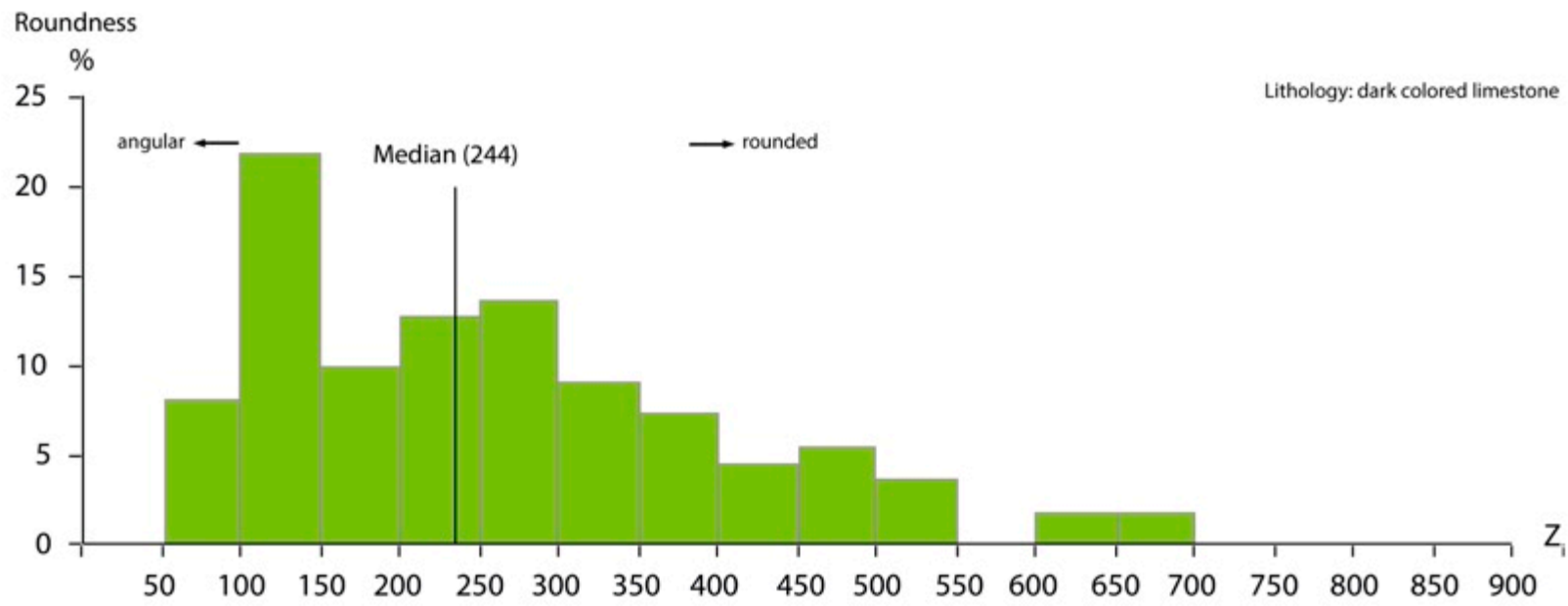

Figure 6. Histogram illustrating roundness index of clasts at the Möhlin site. 


\subsection{Isochron-Burial Dating}

At the Möhlin site twelve samples were collected, of which six samples were processed to extract cosmogenic ${ }^{10} \mathrm{Be}$ and ${ }^{26} \mathrm{Al}$. After leaching, these samples exhibited a total $\mathrm{Al}$ concentration between $49 \mathrm{ppm}$ and $161 \mathrm{ppm}$ (Table 1). The processed samples contain lithologies of quartzite (MÖHL-1, MÖHL-4, MÖHL-5, and MÖHL-7) and sandstone (MÖHL-10). MÖHL-12 is a sediment sample.

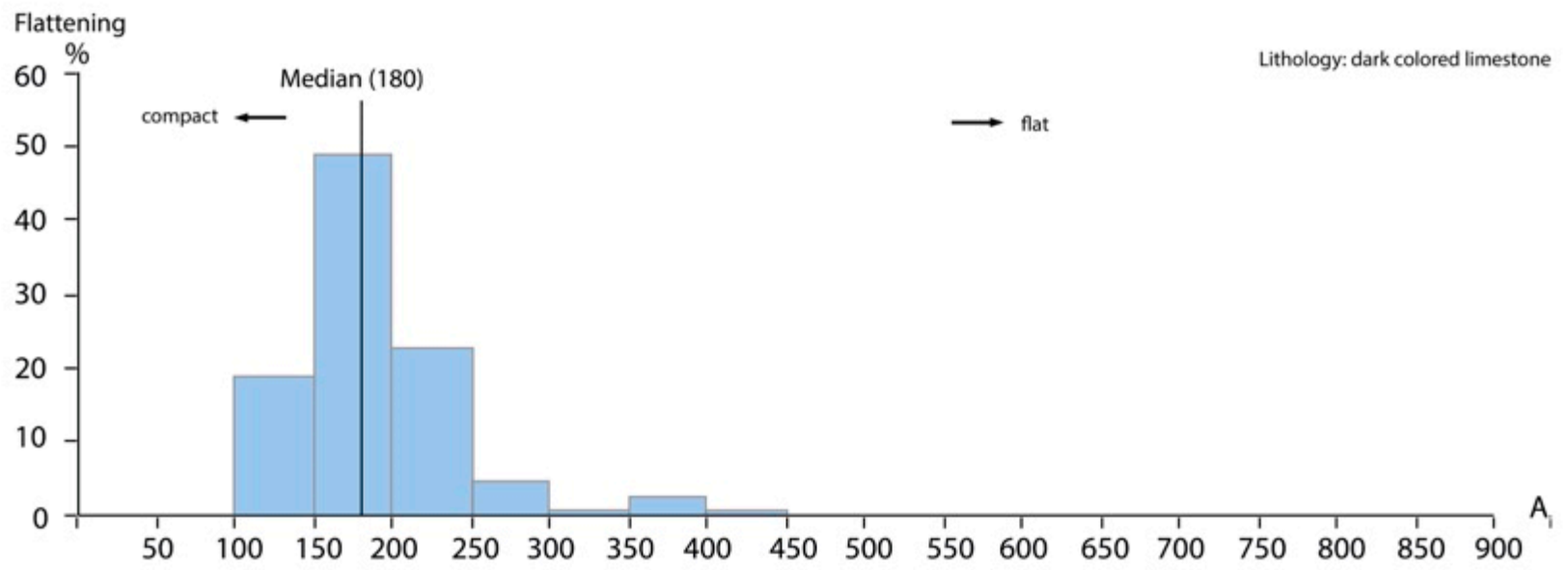

Figure 7. Histogram illustrating flattening index of clasts at the Möhlin site.

The results of the cosmogenic ${ }^{10} \mathrm{Be}$ and ${ }^{26} \mathrm{Al}$ measurements are displayed in Table 2. The ${ }^{10} \mathrm{Be} /{ }^{9} \mathrm{Be}$ ratios range from $1.24 \times 10^{-14}$ to $8.60 \times 10^{-14}$. The relative measurement uncertainty of the ${ }^{10} \mathrm{Be} /{ }^{9}$ Be ratios lies between $4 \%$ and $11 \%$. The full process blank accounts for $3 \%$ to $23 \%$ of the measured ${ }^{10} \mathrm{Be} /{ }^{9} \mathrm{Be}$ ratios. The calculated, blank corrected ${ }^{10} \mathrm{Be}$ concentrations vary between $(3.8 \pm 0.5) \times 10^{3}$ atoms $/ \mathrm{g}$ and $(25.3 \pm 1.3) \times 10^{3}$ atoms $/ \mathrm{g}$. The total $\mathrm{Al}$ amount varies between 3 and $9 \mathrm{mg}$, and the total $\mathrm{Al}$ concentrations between 60 and $190 \mathrm{ppm}$, respectively. The measured ${ }^{26} \mathrm{Al} /{ }^{27} \mathrm{Al}$ ratios range from $1.25 \times 10^{-14}$ to $9.56 \times 10^{-14}$ with relative uncertainties of $3 \%$ to $11 \%$. The calculated concentrations of the ${ }^{26} \mathrm{Al}$ are between $(44.3 \pm 3.2) \times 10^{3}$ atoms $/ \mathrm{g}$ and $(172.0 \pm 13.4) \times 10^{3}$ atoms $/ \mathrm{g}$. The ${ }^{26} \mathrm{Al} /{ }^{10} \mathrm{Be}$ ratio ranges from $6.8 \pm 0.4$ to $13.3 \pm 2.3$. The sample MÖHL-10 was excluded from the modeling of the isochron-burial age, as it lies beyond the two-sigma solution space [49].

For the Bünten Till, a lower isochron-burial age limit of $260 \pm 110 \mathrm{ka}$, with an initial ratio of 6.75, was calculated using the code provided by [45] and personal communication with Darryl Granger. The mean initial ratio of 7.6 yielded an age of $500 \pm 100 \mathrm{ka}$. An upper age boundary of $700 \pm 100 \mathrm{ka}$ was calculated using an initial ratio of 8.4 (Figure 8). In order to explore the contribution of post-burial nuclide production in the measured concentrations, we re-calculated the isochron-burial age by using St [62] and LSDn scaling scheme [70] and based on the Bender approach, which do not include the post burial component (cf. [48]). Use of both calculations with different scaling schemes and Bender code did not alter the isochron-burial age, which indicates a minimum contribution of post-burial production. The $500 \pm 100 \mathrm{ka}$ age will be henceforth utilized with regards to the MEG. 
Table 2. Cosmogenic ${ }^{10} \mathrm{Be}$ and ${ }^{26} \mathrm{Al}$ results of the samples from the Möhlin site.

\begin{tabular}{|c|c|c|c|c|c|c|c|c|c|c|c|c|}
\hline $\begin{array}{c}\text { Sample } \\
\text { Name }\end{array}$ & $\begin{array}{c}\text { Quartz } \\
\text { Dissolved } \\
\text { (g) }\end{array}$ & $\begin{array}{c}{ }^{9} \text { Be Spike } \\
\text { (mg) }\end{array}$ & $\begin{array}{l}{ }^{10} \mathrm{Be} /{ }^{9} \mathrm{Be} \\
\left(\times 10^{-14}\right)\end{array}$ & $\begin{array}{c}\text { Relative } \\
\text { Uncertainty } \\
(\%)\end{array}$ & $\begin{array}{c}\text { Blank } \\
\text { Correction } \\
(\%) \\
\end{array}$ & $\begin{array}{c}{ }^{10} \mathrm{Be} \\
\text { Concentration } \\
\left(\times 10^{3} \text { Atoms } / g\right)\end{array}$ & $\begin{array}{c}\text { Total Al } \\
\text { (ppm) }\end{array}$ & $\begin{array}{l}\text { Total Al } \\
\text { (mg) }\end{array}$ & $\begin{array}{c}{ }^{26} \mathrm{Al} /{ }^{27} \mathrm{Al} \\
\left(\times 10^{-14}\right)\end{array}$ & $\begin{array}{c}\text { Relative } \\
\text { Uncertainty } \\
(\%)\end{array}$ & $\begin{array}{c}{ }^{26} \mathrm{Al} \\
\text { Concentration } \\
\left(\times 10^{3} \text { Atoms } / g\right)\end{array}$ & ${ }^{26} \mathrm{Al} /{ }^{10} \mathrm{Be}$ \\
\hline MÖHL-1 & 34.0800 & 0.1990 & 1.24 & 10.2 & 22.2 & $3.8 \pm 0.5$ & 158 & 5.38 & 1.42 & 10.6 & $50.1 \pm 5.3$ & $13.3 \pm 2.3$ \\
\hline MÖHL-4 & 43.5431 & 0.1980 & 8.60 & 4.8 & 3.2 & $25.3 \pm 1.3$ & 185 & 8.04 & 4.17 & 7.8 & $172.0 \pm 13.4$ & $6.8 \pm 0.4$ \\
\hline MÖHL-5 & 49.9954 & 0.1991 & 1.75 & 7.4 & 15.8 & $3.9 \pm 0.4$ & 159 & 7.93 & 1.25 & 7.2 & $44.3 \pm 3.2$ & $11.3 \pm 1.3$ \\
\hline MÖHL-7 & 35.5300 & 0.1990 & 3.55 & 6.3 & 7.8 & $12.2 \pm 0.8$ & 106 & 3.78 & 3.85 & 5.5 & $91.5 \pm 5.0$ & $7.5 \pm 0.7$ \\
\hline${ }^{1}$ MÖHL-12 & 50.0300 & 0.2000 & 7.14 & 4.2 & 3.9 & $18.3 \pm 0.8$ & 63 & 3.16 & 9.56 & 3.9 & $134.5 \pm 5.3$ & $7.3 \pm 0.4$ \\
\hline
\end{tabular}

${ }^{1}$ Sediment sample. Accelerator mass spectrometry (AMS) measurement errors at $1 \sigma$ level, including the statistical (counting) error, the uncertainty of standard normalization, and the propagated error of blank correction. The error weighted average ${ }^{10} \mathrm{Be} /{ }^{9} \mathrm{Be}$ full-process blank ratio was $(2.76 \pm 0.18) \times 10^{-15}$. ${ }^{26} \mathrm{Al} /{ }^{10} \mathrm{Be}$ ratios were calculated with the CRONUS-Earth exposure age calculator and were referenced to 07KNST (http://hess.ess.washington.edu/math/al_be_v23/al_be_multiple_v23.html; accessed on 13 January 2021); see [59] and update from v.2.2 to v.2.3 published by Balco in June 2016). 


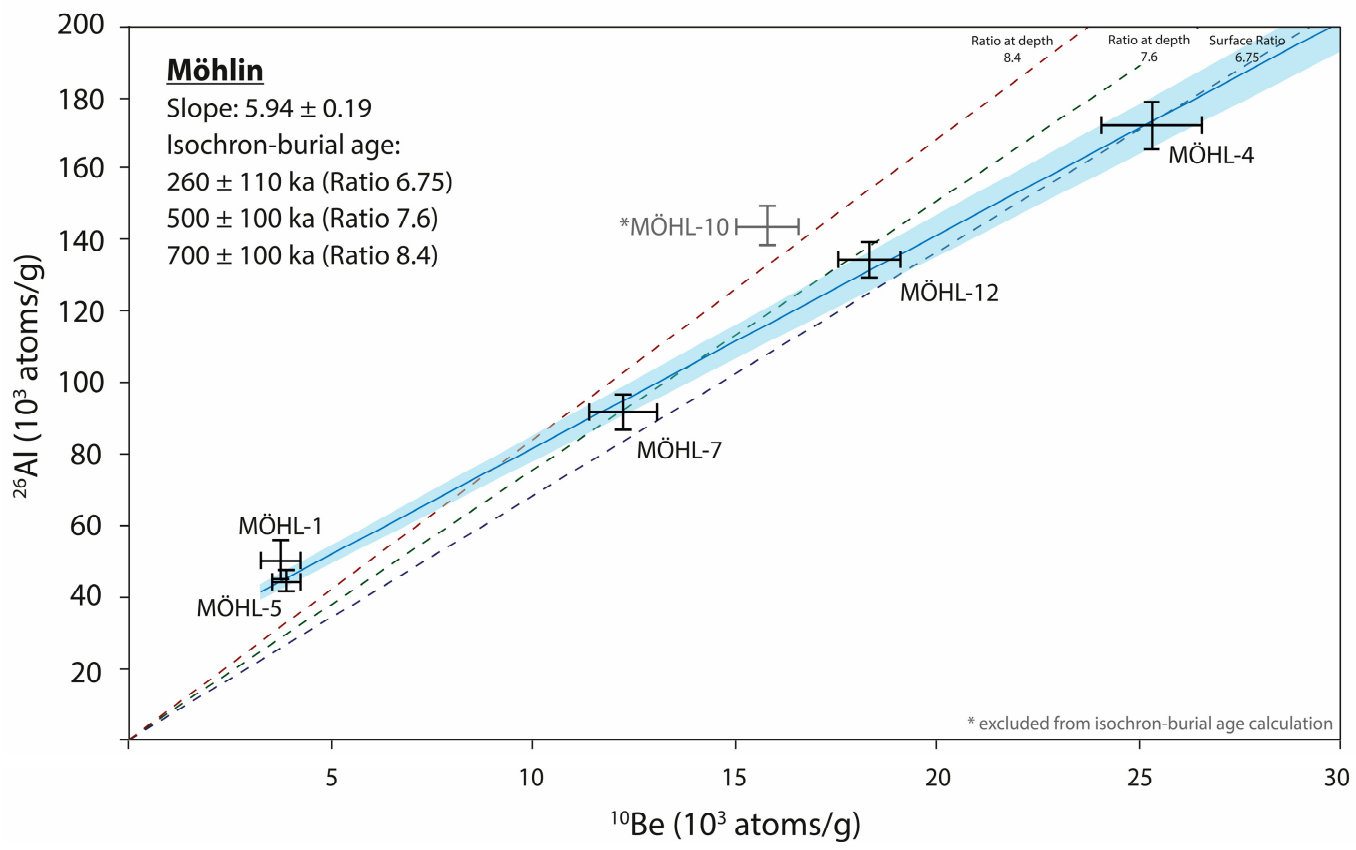

Figure 8. Isochron plot of the samples from the Möhlin site (the samples are plotted with $1 \sigma$ uncertainties and the isochron-burial ages calculated with the initial ratios $6.75,7.6$, and 8.4). The best fit isochron-line is indicated in blue and the light blue envelope shows the $1 \sigma$ solution space. The sample indicated in gray and labeled with an asterisk $\left.{ }^{*}\right)$ is defined as an outlier and therefore excluded from the isochron-burial age calculation.

\section{Discussion}

\subsection{Provenance of the Sediments}

Given the proximity of Möhlin to the Black Forest, it is important to establish whether the till in the Bünten gravel pit represents the most extensive position of Alpine glaciers or has been deposited by a paleoglacier from the Black Forest. The petrography of the clasts is essential to understand the origin of the paleoglacier. Several varieties of limestone $(60 \%)$ reported from Möhlin, including the dark colored, gray colored, light colored, and siliceous limestone clasts, possibly have their origins in the Helvetic and Penninic Nappes of the Alps [71-73]. These nappes cover extensive areas and therefore the precise provenance cannot be determined. The ocher colored limestone, oosparite, and sparitic limestone clasts probably originated from the Jura Mountains in the northern and western parts of the northern Alpine Foreland and/or south of the Black Forest [71-73]. The quartzite clasts are currently exposed in the Valaisian Alps and eastern Central Alps, and have also been observed in the Molasse Conglomerates [74-76]. The composition of the crystalline components from the till indicates a Black Forest as well as an Alpine origin.

The presence of Alpine and Black Forest origin clasts in the Bünten Till can be explained by the reworking of previously deposited Alpine clasts by a glacier initiating from the Black Forest or vice versa. Previous studies reported the presence of Alpine and Black Forest lithologies at various locations between Brennet and Laufenburg (Figure 1) and thus, numerous theories were proposed for the origin of the paleoglacier. In 1895, Gutzwiller [19] observed the coexistence of the Alpine and Black Forest material in a glacial deposit, but did not make a clear statement regarding the origin of this paleoglacier. Reichelt [77] concluded that the two glaciers merged to the east, close to the city of Laufenburg (Figure 1). However, Pfannenstiel [78] suggested that the glacier initiated from the Black Forest and coalesced with the Alpine glacier approximately $5 \mathrm{~km}$ east of Möhlin (Figure 1). A few studies proposed that the glacier from the Wehra Valley advanced close to Möhlin, but did not reach the Möhlinerfeld [79,80] (Figure 1). Müller-Dick [22] suggested that the glacier 
depositing the Bünten Till was of Alpine origin, while a second glacier advance depositing the Zeiningen Till originated from the Black Forest.

The lithology of a paleoglacier from the Black Forest should ideally contain contributions of: red colored granites, minor amounts of Mesozoic carbonates, and a few Tertiary rocks $[71-73,81]$. A southbound advancement of the Black Forest paleoglacier potentially enabled its encounter with some Alpine clasts, reworked from the deposits along the course of the River Rhine. In contrast, theoretically, a paleoglacier from the Alps would have predominantly transported carbonate clasts from the Helvetic and Penninic Nappes, along with quartzite clasts, crystalline clasts (such as Julier granite, Aare granite, and Serpentinites, among others), and a few Mesozoic rocks from the Jura Mountains, allowing limited contribution of the clasts from the Black Forest. Clast petrographic analysis during this study revealed coexistence of sediments from both provenances. The components from the Black Forest demonstrate a rather small relative abundance.

The morphometry of the clasts embedded in the Bünten Till points towards a glacially influenced sediment [35,82]. According to Cailleux and Tricart [35], and Schlüchter [82], clasts with a roundness index between 150 and 300 were deposited in the proximity of a glaciofluvial environment. Two third of the clasts from the Bünten Till show $Z_{i}$ values below 300 , of which a third contain values between 50 and 150 , which indicate a glacial deposition. The clasts with $Z_{\mathrm{i}}$ values above 300 , therefore, probably represent better rounded clasts and are interpreted as indicators for reworked sediment [82]. We accordingly conclude that one third of the quartz vein clasts in the Bünten Till are fresh material delivered from the Alps, whereas, two thirds appear to bear evidence of reworking by the glacier. The $A_{i}$ values point towards a compact shape and, therefore, glacial and glaciofluvial transport in contrast to the flat and disc shaped clasts, which are interpreted as evidence of a fluvial transport [34]. In brief, we propose that the Bünten Till was deposited by a glacier descending from the Alps based on the petrographical composition of the sediment, the morphometry, and the measured paleoflow direction towards the northwest. The Black Forest lithologies encountered in the sediment were most probably eroded from outcrops located further east of Möhlin and close to the River Rhine (Figure 1).

\subsection{Age of the MEG in the Northern Hemisphere}

Previous studies have tentatively reconstructed the age of the MEG based on the morphostratigraphy of the northern Alpine Foreland, whereas the obtained $500 \pm 100 \mathrm{ka}$ corresponds to the age of the most extensive position of Alpine glaciers. The chronology of the MEG lies within the time range suggested by previous studies and implied by the morphostratigraphy of the northern Alpine Foreland $[2,4,16,17]$. Schlüchter $[2,16]$ suggested that this advance occurred after the Deckenschotter glaciations and the Brunhes/Matuyama transition. Based on the OSL ages from the loess cover, Gaar et al. [17] tentatively attributed the deposition of the Zeiningen Till to MIS 6, thus implying that the MEG predates the Zeiningen Till (Figure 3a).

Based on the existing data and results obtained from this study, we suggest the following chronostratigraphy for the Möhlinerfeld area. At approximately $500 \mathrm{ka}$, the Alpine glaciers reached their most extensive position. The Bünten Till indicates that a glacier lobe covered the Möhlinerfeld; however, evidence for the thickness of the ice and the position of the ice margins at that time is lacking. The measured paleoflow directions suggest that the ice margin was located NW of the Bünten gravel pit. According to Frei [10], the Rhone Lobe covered the Möhlinerfeld during the MEG. Such an assumption implies that the Rhone Lobe reached an approximate minimum length of $315 \mathrm{~km}$. This further implies that the glacier during the MEG was nearly $35 \mathrm{~km}$ longer than that during the LGM. The deposition of the gravels and the Zeiningen Till located on top of the Bünten Till occurred between $500 \mathrm{ka}$ and $60 \mathrm{ka}$, as per the age of the loess coverage [17] (Figure 3a). An age of $160 \mathrm{ka}$, corresponding to the MIS 6, was suggested for the Zeiningen Till [17]. Assuming that the Zeiningen Till is of the MIS 6 age, the Bünten Gravel would have been either deposited during the MEG or the Habsburg glaciation, with the Wallbach Gravel 
overlying the Bünten Gravel during the Habsburg or Hagenholz/first advance of the Beringen glaciation, respectively (Figure 3a,b). The deposition of the Möhlinerfeld Gravel can be tentatively attributed to the Beringen glaciation (Figure 3a).

Glaciers played an important role in shaping the Quaternary landscapes of the northern Swiss Foreland. Glaciers that advanced onto the northern Alpine Foreland sculpted the overdeepened valleys (up to $300 \mathrm{~m}$ in depth) (see [83] and references therein). The MEG is considered responsible for the commencement of the overdeepened valley formation $[4,12]$. Therefore, we suggest that the first overdeepened valley formed not later than approximately $500 \mathrm{ka}$. Recently, several drill cores were obtained from overdeepened valleys in the Swiss northern Alpine Foreland to comprehensively analyze the infill and to reconstruct the glaciation history [83-87]. Sediments from the base of the investigated overdeepened valley fills were dated to approximately $180 \mathrm{ka}$ [83-87]. Some of these also represent an older sedimentary infill [74]. According to these findings, the beginning of the overdeepening has been assigned to a glacial advance at $260 \mathrm{ka}$ or older [83]. In the Lower Aare Valley, the presence of different sediment units implies that during $160 \mathrm{ka}$ to $180 \mathrm{ka}$, the area was dominated by a periglacial setting; the lowermost sands covering a glacial diamicton are older than $180 \mathrm{ka}$ [87]. The presence of glaciolacustrine sediments, dated by applying OSL, indicate that glacial lakes dominated the Wehn Valley and the Lower Glatt Valley between ca. $130 \mathrm{ka}$ and ca. $180 \mathrm{ka}[83,86]$ as well as between ca. $180 \mathrm{ka}$ and $>260 \mathrm{ka}[84,86]$. Assuming the challenges involved in OSL dating of proglacial sediments, the ages of roughly $260 \mathrm{ka}$ might also be related to the upper limit of the OSL dating technique and can be reliable up to $200 \mathrm{ka}[88,89]$. The upper dating limit with OSL is given by the saturation of the dose, usually resulting in an age of $150 \mathrm{ka}$, but few deposits can be dated up to ca. $400 \mathrm{ka}$ [89-92]. Based on these results, the MEG still possibly remains responsible for the first overdeepened valleys, albeit inconclusively.

Owing to the limitations of the OSL technique, with a few exceptions a chronology of only up to ca. $400 \mathrm{ka}$ can be dated; that is, the OSL helps reconstruct chronology of deposits older than the LGM [93-104]. It is possible, however, that evidence of glaciation at $500 \mathrm{ka}$ exists somewhere in the Alps. In the Upper Rhine Graben (URG) about $300 \mathrm{~km}$ north of Möhlin, recently deposited sediments in a fluvial environment partially influenced by gravitational processes were dated to $454 \pm 29 \mathrm{ka}$ and attributed to the MEG [96]. Two phases for the deposition of HT-complex sediments were revealed by OSL ages in the northern Alpine Foreland: one at approximately $160 \mathrm{ka}$ and another at $260 \mathrm{ka}$ (Figure 9). HT deposits, $20 \mathrm{~km}$ to the west of Möhlin, were dated at approximately $236 \mathrm{ka}$ by OSL, suggesting that the underlying gravel units were deposited by a glaciation older than ca. $240 \mathrm{ka}$ [93]. The ${ }^{10} \mathrm{Be}$ depth-profile age indicates that at $270 \mathrm{ka}$ this area was characterized by a distal glaciofluvial environment [94]. These two phases were also identified based on glaciofluvial sediments in Southern Germany [98]. In Austria, the glaciofluvial sediments from the penultimate glaciation, attributed to the HT, were dated to $140 \mathrm{ka}[99,100]$. In the Southern Alps, a cold phase was determined at ca. $250 \mathrm{ka}$ [101], but there is some evidence that these sediments might be of earlier glaciations [102,103]. No deposits older than the LGM have been dated in the French Alps; however, there is evidence that there were glaciers present during the Middle Pleistocene [104]. These ages of the HT exhibit that the MEG is clearly older and should therefore be classified separately. In addition, very few MEG deposits have been dated so far. Therefore, the ca. $500 \mathrm{ka}$ of the Bünten Till represents the only time constraint for the MEG in the Alps. 


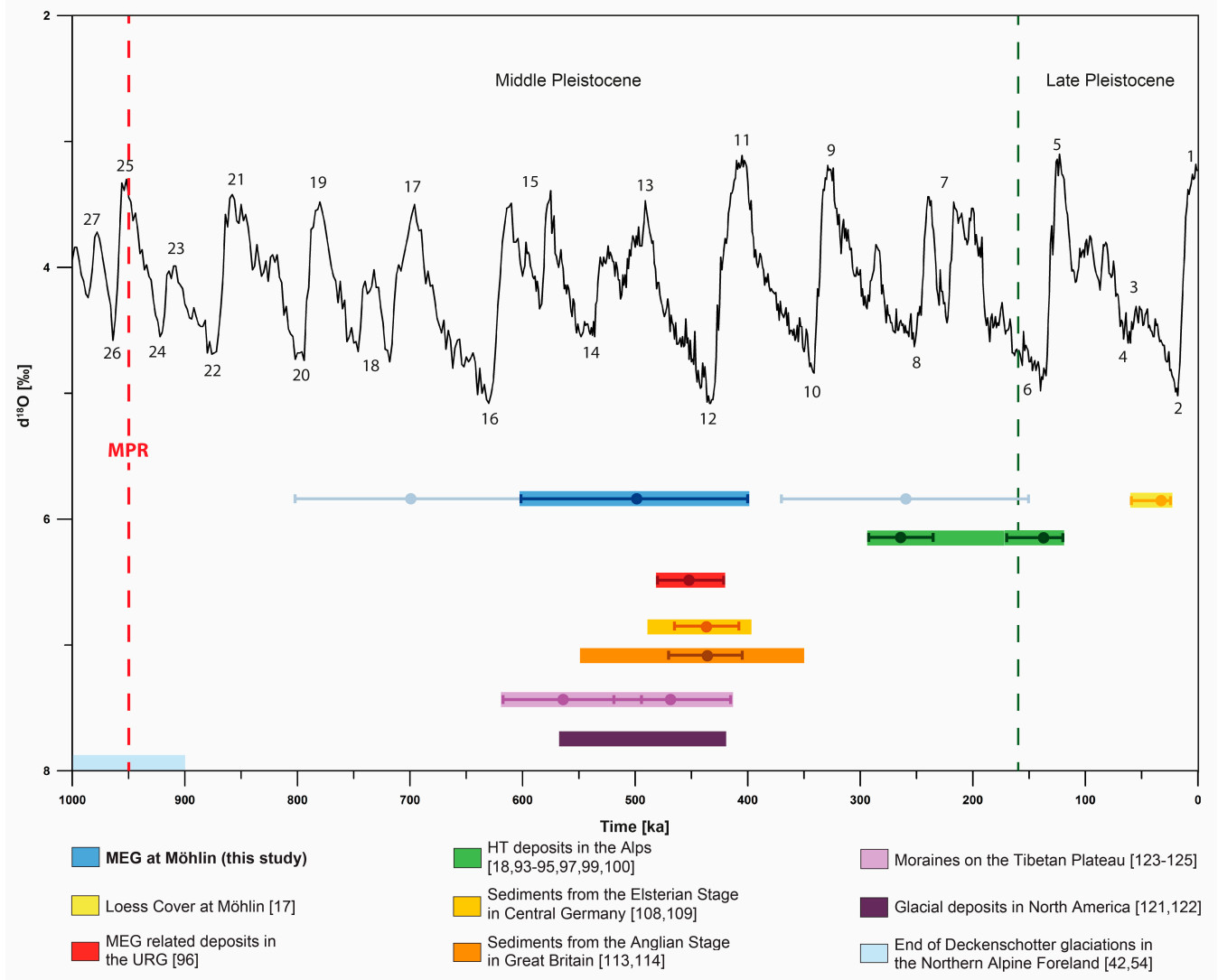

Figure 9. $\delta^{18} \mathrm{O}$ variation in the last $1 \mathrm{Ma}$ (modified after [15]). The upper error ranges of the MEG, with an age of $500 \pm 100 \mathrm{ka}$, overlap with those of the Elsterian stage in Northern Europe, the Anglian stage in Great Britain, moraines on the Tibetan Plateau, while its lower error ranges overlap with glaciofluvial sediments of North America. The Alpine glaciations of $250 \mathrm{ka}$ and $160 \mathrm{ka}$ represent separate glaciation events that do not correlate with the MEG. The light blue bar indicates the end of Deckenschotter glaciations, which took place between ca. 2.6 and $0.9 \mathrm{Ma}[42,54]$. The red dashed line indicates the Mid Pleistocene Revolution (MPR) occurring at around 0.95 Ma [105] and the green one the boundary between the Middle and Late Pleistocene [1].

At approximately $500 \pm 100 \mathrm{ka}$, the glaciers apparently reached their most extensive position, not only in the Alps but also in other parts of Europe and of the northern hemisphere [106] (Figure 9). The Fennoscandian ice sheet reached its most extensive position during the Elsterian glaciation, covering Northern Europe and advancing up to Central Germany [107-109]. Fluvial sediments overlying Elsterian till were analyzed with the luminescence technique and dated between $447 \pm 52 \mathrm{ka}$ and $387 \pm 48 \mathrm{ka}$, indicating that the Elsterian stage occurred during MIS 12 [108]. Dated glaciofluvial sediments indicate a glacier advance during the Elsterian glaciation between $461 \pm 34 \mathrm{ka}$ and $421 \pm 25 \mathrm{ka}$ [109] (Figure 9). In the Netherlands and the western part of Germany, archives of the Elsterian stage exist, which are not considered to represent the most extensive glaciation [110,111]. The MEG is considered as a glacier advance that initiated the overdeepening of valleys not only in the Swiss northern Alpine Foreland but also in Northern Europe (Elsterian glaciation) [112]. Glaciofluvial deposits indicate that the British ice sheet had the maximum extent (the Anglian stage) during $440 \mathrm{ka}[113,114]$ (Figure 9). The presence of the Eurasian ice sheet ( $500 \mathrm{ka}$ ) can be observed in Russia. A till layer overlying interglacial sediments has been dated to $510 \mathrm{ka}$ using the thermoluminescence technique [115]. This till layer corresponds to the Oka glaciation (tentatively correlating with the Elsterian glaciation) at 500-460 ka [116]. Although the Oka glaciation occurred comparably with the Möhlin glaciation, it did not reach its most extensive position in that area. The Don glaciation, considered to have had the largest extent, occurred prior to the Oka glaciation and therefore 
predates $500 \mathrm{ka}[111,115]$. The $\mathrm{U} / \mathrm{Th}$ analysis of the secondary carbonates precipitated in the pores of the glaciofluvial deposits in the Balkan Mountains suggests that the MEG occurred between 470 and $420 \mathrm{ka}$ [117-120]. Glaciations dating 500 ka have also been reported from North America [121,122]. There are, for instance, glacial deposits overlain by ca. $470 \mathrm{ka}$ old basalts and underlain by marine deposits of $570 \mathrm{ka}$ [121] or a till deposit with a suggested minimum age of 424-478 ka [122] (Figure 9). Evidence of a 500 ka old glaciation have been retrieved from the Tibetan Plateau, where glacial deposits were dated to $460-571$ ka by the electron spin resonance (ESR) technique [123-125] (Figure 9). This indicates that the age of the MEG is consistent with other glacier advances in the northern hemisphere.

\section{Conclusions}

The Bünten gravel pit close to Möhlin, deposited by the MEG, was comprehensively examined during this study. Based on the petrographic analyses and the results of paleoflow direction, we conclude that the glacier originated from the Alps and that the Black Forest clasts were incorporated into the till due to reworking of the nearby sediments. Moreover, the isochron-burial dating of the Bünten Till to $500 \pm 100$ ka provides the first direct chronology for the MEG, thus addressing the complex chronostratigraphy of the Swiss northern Alpine Foreland. However, for improved understanding regarding the age and the extent of the most extensive glaciation in the Alps, further studies on stratigraphy and chronostratigraphy of MEG deposits are essential. We thus infer that the MEG is apparently synchronous with other glacier advances in the northern hemisphere.

Author Contributions: Conceptualization, N.A. and C.D.; methodology, C.D. and N.A.; fieldwork, C.D., N.A. and H.R.G.; sample preparation, C.D. and N.A.; AMS-measurements, M.C., C.V. and P.G.; investigation, C.D. and N.A.; writing, original draft preparation, C.D. with contributions from all authors; supervision, N.A.; project administration, N.A.; and funding acquisition, N.A. All authors have read and agreed to the published version of the manuscript.

Funding: This research was funded by the Swiss Federal Nuclear Safety Inspectorate (ENSI), grant number CTR 00314.

Data Availability Statement: All generated and analyzed data during this study has been included in this article.

Acknowledgments: We would like to thank Susan Ivy Ochs at ETH Zurich and Marius Büchi at the University of Bern for their help and support during the sampling campaign. We are grateful to Julia Gajic at the University of Bern for her help in preparing the samples. We are thankful to Niklaus Waber, Priska Bähler, and Christopher Pichler at the University of Bern for the ICP measurements. We would also like to thank the AMS facility team at ETH Zurich for the AMS measurements.

Conflicts of Interest: The authors declare no conflict of interest. The funders had no role in the design of the study, collection, analyses, or interpretation of data, writing of the manuscript, or in the decision to publish the results.

\section{References}

1. Cohen, K.M.; Finney, S.C.; Gibbard, P.L.; Fan, J.-X. The ICS International Chronostratigraphic Chart. Episodes 2013, 36, $199-204$. [CrossRef] [PubMed]

2. Schlüchter, C. The Swiss glacial record-A schematic summary. In Quaternary Glaciations-Extent and Chronology; Elsevier B.V.: Amsterdam, The Netherlands, 2004; Volume 2, pp. 413-418. ISBN 9780444514622.

3. Graf, H.R. Stratigraphie von Mittel- und Spätpleistozän in der Nordschweiz. Beiträge zur Geol. Karte der Schweiz; Bundesamt für Landestopographie, Swisstopo: Wabern, Switzerland, 2009; Volume 168.

4. Preusser, F.; Graf, H.R.; Keller, O.; Krayss, E.; Schlüchter, C. Quaternary glaciation history of northern Switzerland. E\&G Quat. Sci. J. 2011, 60, 282-305. [CrossRef]

5. Ellwanger, D.; Wielandt-Schuster, U.; Franz, M.; Simon, T. The Quaternary of the southwest German Alpine Foreland (BodenseeOberschwaben, Baden-Württemberg, Southwest Germany). EEG Quat. Sci. J. 2011, 60, 306-328. [CrossRef]

6. Keller, O. Erwägungen zur Korrelation mittelpleistozäner Relikte des Rheingletschers mit der nordschweizer Stratigraphie. EEG Quat. Sci. J. 2014, 63, 19-43. [CrossRef]

7. Schlüchter, C. Das Eiszeitalter in der Schweiz; Stiftung Landschaft und Kies: Rubigen, Switzerland, 2010; p. 4. 
8. Keller, O.; Krayss, E. Mittel-und spätpleistozäne Stratigraphie und Morphogenese in Schlüsselregionen der Nordschweiz. EEG Quat. Sci. J. 2010, 59, 88-119. [CrossRef]

9. $\quad$ Penck, A.; Brückner, E. Die Alpen im Eiszeitalter; H. Tauchnitz: Leipzig, Germany, 1909; p. 1199.

10. Frei, R. Über die Ausbreitung der Diluvialgletscher in der Schweiz. Beiträge zur Geol. Karte der Schweiz; Bundesamt für Landestopographie, Swisstopo: Wabern, Switzerland, 1912; Volume 41.

11. Hantke, R. Eiszeitalter Kalt-/Warmzeit-Zyklen und Eistransport im alpinen und voralpinen Raum; Hep Verlag Ag: Bern, Switzerland, 2011; ISBN 978-3-7225-0121-5.

12. Ellwanger, D. Eine landschaftsübergreifende Lockergesteinsgliederung vom Alpenrand zum Oberrhein. In Landschaftsgeschichte im europäischen Rheinland; Schirmer, W., Ed.; Lit Verlag: Münster, Germany, 2003; pp. 81-124.

13. Fiebig, M.; Preusser, F. Pleistocene glaciations of the northern Alpine Foreland. Geogr. Helv. 2008, 63, 145-150. [CrossRef]

14. Spell, T.L.; Mcdougall, I. Revisions to the Age of the Brunhes-Matuyama boundary and the Pleistocene geomagnetic polarity timescale. Geophys. Res. Lett. 1992, 19, 1181-1184. [CrossRef]

15. Lisiecki, L.E.; Raymo, M.E. A Pliocene-Pleistocene stack of 57 globally distributed benthic $\delta^{18}$ O records. Paleoceanography 2005, 20, 1-17. [CrossRef]

16. Schlüchter, C. The Deglaciation of the Swiss-Alps: A paleoclimatic event with chronological problems. Bull. L'association Française Pour L'étude Quat. 1988, 2, 141-145. [CrossRef]

17. Gaar, D.; Preusser, F. Age of the Most Extensive Glaciation of Northern Switzerland: Evidence from the scientific drilling at Möhliner Feld. EEG Quat. Sci. J. 2017, 66, 1-5. [CrossRef]

18. Dehnert, A.; Preusser, F.; Kramers, J.D.; Akçar, N.; Kubik, P.W.; Reber, R.; Schlüchter, C. A multi-dating approach applied to proglacial sediments attributed to the Most Extensive Glaciation of the Swiss Alps. Boreas 2010, 39, 620-632. [CrossRef]

19. Gutzwiller, A. Die Diluvialbildungen der Umgebung von Basel. Verh. Nat. Ges. Basel 1895, 10, 512-690. [CrossRef]

20. Bini, A.; Buoncristiani, J.F.; Couterrand, S.; Ellwanger, D.; Felber, M.; Florineth, D.; Graf, H.R.; Keller, O.; Kelly, M.; Schlüchter, C.; et al. Die Schweiz während dem letzteiszeitlichen Maximums (LGM); Bundesamt für Landestopographie, Swisstopo: Wabern, Switzerland, 2009.

21. Dick, K.A.; Graf, H.-R.; Müller, B.U.; Hartmann, P.; Schlüchter, C. Das nordalpine Wasserschloss und seine eiszeitgeologische Umgebung. Eclogae Geol. Helv. 1996, 89, 635-645.

22. Müller-Dick, K. Das Möhlinerfeld im Hochrheintal. In DEUQUA 2000, Bern, Exkursionsführer, Exk. A1; Kelly, M., Linden, U., Schlüchter, C., Eds.; DEUQUA: Hannover, Germany, 2000; pp. 10-14.

23. Pfirter, U.; Jordan, P.; Graf, H.R.; Burger, H.; Pietsch, J.; Huber, M.; Kiefer, S.; Grezet, C.; Maise, C.; Burkhalter, R. Geologischer Atlas der Schweiz 1:25`000. Blatt Sissach (1068) mit Südteil von Blatt Rheinfelden (1048)-Erläuterungen; Bundesamt für Landestopographie, Swisstopo: Wabern, Switzerland, 2019; ISBN 9783302401003.

24. Frei, R. Monographie des Schweizerischen Deckenschotters. Beiträge zur Geol. Karte der Schweiz; Bundesamt für Landestopographie, Swisstopo: Wabern, Switzerland, 1912; Volume 37.

25. Graf, H.R. Die Deckenschotter der Zentralen Nordschweiz. Ph.D. Thesis, Swiss Federal Institute of Technology Zurich, Zurich, Switzerland, 1993.

26. Schlüchter, C. Eiszeitliche Lockergesteine-Geologie, Genese und Eigenschaften. Ein Beitrag zu den Beziehungen zwischen fundamentaler und angewandter Eiszeitgeologie, Habilitationsschrift; Swiss Federal Institute of Technology Zurich: Zurich, Switzerland, 1989.

27. Weltje, G.J.; von Eynatten, H. Quantitative provenance analysis of sediments: Review and outlook. Sediment. Geol. 2004, 171, 1-11. [CrossRef]

28. Lindsey, D.A.; Langer, W.H.; Van Gosen, B.S. Using pebble lithology and roundness to interpret gravel provenance in piedmont fluvial systems of the Rocky Mountains, USA. Sediment. Geol. 2007, 199, 223-232. [CrossRef]

29. Adelsberger, K.A. Sedimentology. In Encyclopedia of Geoarchaeology; Gilbert, A.S., Ed.; Springer: Dordrecht, The Netherlands, 2017; pp. 764-772. ISBN 978-1-4020-4409-0.

30. Claude, A.; Akçar, N.; Ivy-Ochs, S.D.; Schlunegger, F.; Kubik, P.W.; Dehnert, A.; Kuhlemann, J.; Rahn, M.; Schlüchter, C. Timing of early Quaternary gravel accumulation in the Swiss Alpine Foreland. Geomorphology 2017, 276, 71-85. [CrossRef]

31. Günther, D. Der Schwarzwald und seine Umgebung. Geologie-Mineralogie-Bergbau-Umwelt und Geotourismus; Rothe, P., Ed.; Gebr Borntraeger: Stuttgart, Germany, 2010; 302p.

32. Benn, D.I. Clast Morphology. A Practical Guide to the Study of Glacial Sediments; Evans, D.J.A., Benn, D.I., Eds.; Routledge, Taylor \& Francis Group: London, UK, 2004; pp. 78-92.

33. Cailleux, A. L'indice d'émoussé: Définition et première application. Société Géologique Fr. 1947, 13, $250-252$.

34. Sneed, E.D.; Folk, R.L. Pebbles in the Lower Colorado River, Texas a study in particle morphogenesis. J. Geol. 1958, 66, 114-150. [CrossRef]

35. Cailleux, A.; Tricart, J. Initiation a l'étude des Sables et des Galets (3 Volumes); Centre de Documentation Universitaire: Paris, France, 1959; 772p.

36. Boulton, G.S. Boulder shapes and grain-size distributions of debris as indicators of transport paths through a glacier and till genesis. Sedimentology 1978, 25, 773-799. [CrossRef]

37. Benn, D.I.; Ballantyne, C.K. Reconstructing the transport history of glacigenic sediments: A new approach based on the co-variance of clast form indices. Sediment. Geol. 1994, 91, 215-227. [CrossRef] 
38. Lukas, S.; Graf, A.; Coray, S.; Schlüchter, C. Genesis, stability and preservation potential of large lateral moraines of Alpine valley glaciers-towards a unifying theory based on Findelengletscher, Switzerland. Quat. Sci. Rev. 2012, 38, 27-48. [CrossRef]

39. Chandler, D.M.; Hubbard, B. Quantifying sample bias in clast fabric measurements. Sedimentology 2008, 55, 925-938. [CrossRef]

40. Boggs, S. Petrology of Sedimentary Rocks, 2nd ed.; Cambridge University Press: Cambridge, UK, 2009 ; ISBN 9780521897167.

41. Balco, G.; Rovey, C.W. An isochron method for cosmogenic-nuclide dating of buried soils and sediments. Am. J. Sci. 2008, 308, 1083-1114. [CrossRef]

42. Knudsen, M.F.; Nørgaard, J.; Grischott, R.; Kober, F.; Egholm, D.L.; Hansen, T.M.; Jansen, J.D. New cosmogenic nuclide burialdating model indicates onset of major glaciations in the Alps during Middle Pleistocene Transition. Earth Planet. Sci. Lett. 2020, 549, 116491. [CrossRef]

43. van Buuren, U.; Prins, M.A.; Wang, X.; Stange, M.; Yang, X.; van Balen, R.T. Fluvial or aeolian? Unravelling the origin of the silty clayey sediment cover of terraces in the Hanzhong Basin (Qinling Mountains, central China). Geomorphology 2020, $367,107294$. [CrossRef]

44. Darling, A.L.; Karlstrom, K.E.; Granger, D.E.; Aslan, A.; Kirby, E.; Ouimet, W.B.; Lazear, G.D.; Coblentz, D.D.; Cole, R.D. New incision rates along the Colorado River system based on cosmogenic burial dating of terraces: Implications for regional controls on Quaternary incision. Geosphere 2012, 8, 1020-1041. [CrossRef]

45. Erlanger, E.D.; Granger, D.E.; Gibbon, R.J. Rock uplift rates in South Africa from isochron burial dating of fluvial and marine terraces. Geology 2012, 40, 1019-1022. [CrossRef]

46. Balco, G.; Soreghan, G.S.; Sweet, D.E.; Marra, K.R.; Bierman, P.R. Cosmogenic-nuclide burial ages for Pleistocene sedimentary fill in Unaweep Canyon, Colorado, USA. Quat. Geochronol. 2013, 18, 149-157. [CrossRef]

47. Çiner, A.; Doğan, U.; Yildirim, C.; Akçar, N.; Ivy-Ochs, S.; Alfimov, V.; Kubik, P.W.; Schlüchter, C. Quaternary uplift rates of the Central Anatolian Plateau, Turkey: Insights from cosmogenic isochron-burial nuclide dating of the Kizilirmak River terraces. Quat. Sci. Rev. 2015, 107, 81-97. [CrossRef]

48. Bender, A.M.; Amos, C.B.; Bierman, P.; Rood, D.H.; Staisch, L.; Kelsey, H.; Sherrod, B. Differential uplift and incision of the Yakima River terraces, central Washington State. J. Geophys. Res. Solid Earth 2016. [CrossRef]

49. Schaller, M.; Ehlers, T.A.; Stor, T.; Torrent, J.; Lobato, L.; Christl, M.; Vockenhuber, C. Timing of European fluvial terrace formation and incision rates constrained by cosmogenic nuclide dating. Earth Planet. Sci. Lett. 2016, 451, 221-231. [CrossRef]

50. Zhao, Z.; Granger, D.; Zhang, M.; Kong, X.; Yang, S.; Chen, Y.; Hu, E. A test of the isochron burial dating method on fluvial gravels within the Pulu volcanic sequence, West Kunlun Mountains, China. Quat. Geochronol. 2016, 34, 75-80. [CrossRef]

51. Akçar, N.; Ivy-Ochs, S.; Alfimov, V.; Schlunegger, F.; Claude, A.; Reber, R.; Christl, M.; Vockenhuber, C.; Dehnert, A.; Rahn, M.; et al. Isochron-burial dating of glaciofluvial deposits: First results from the Swiss Alps. Earth Surf. Process. Landf. 2017, 42, $2414-2425$. [CrossRef]

52. Tu, H.; Shen, G.; Granger, D.; Yang, X.; Lai, Z. Isochron 26Al/10Be burial dating of the Lantian hominin site at Gongwangling in Northwestern China. Quat. Geochronol. 2017, 41, 174-179. [CrossRef]

53. Litty, C.; Schlunegger, F.; Akçar, N.; Lanari, P.; Christl, M.; Vockenhuber, C. Possible climatic controls on the accumulation of Peru's most prominent alluvial fan: The Lima Conglomerate. Earth Surf. Process. Landf. 2018, 44, 991-1003. [CrossRef]

54. Claude, A.; Akçar, N.; Ivy-Ochs, S.; Schlunegger, F.; Kubik, P.W.; Christl, M.; Vockenhuber, C.; Kuhlemann, J.; Rahn, M.; Schlüchter, C. Changes in landscape evolution patterns in the northern Swiss Alpine Foreland during the mid-Pleistocene revolution. Geol. Soc. Am. Bull. 2019, 131, 2056-2078. [CrossRef]

55. Granger, D.E.; Muzikar, P.F. Dating sediment burial with in situ-produced cosmogenic nuclides: Theory, techniques, and limitations. Earth Planet. Sci. Lett. 2001, 188, 269-281. [CrossRef]

56. Maxeiner, S.; Synal, H.A.; Christl, M.; Suter, M.; Müller, A.; Vockenhuber, C. Proof-of-principle of a compact 300 kV multi-isotope AMS facility. Nucl. Instrum. Methods Phys. Res. Sect. B Beam Interact. Mater. At. 2019, 439, 84-89. [CrossRef]

57. Christl, M.; Gautschi, P.; Synal, H.A. 10Be on the 0.3 MV MILEA System. In Annual Report 2020-Laboratory of Ion Beam Physics; Librum Publishers and Editors: Basel, Switzerland, 2021; p. 12.

58. Gautschi, P.; Vockenhuber, C.; Synal, H.A. 26Al on the 0.3 MV MILEA System. In Annual Report 2020-Laboratory of Ion Beam Physics; Librum Publishers and Editors: Basel, Switzerland, 2021; p. 13.

59. Balco, G.; Stone, J.O.; Lifton, N.A.; Dunai, T.J. A complete and easily accessible means of calculating surface exposure ages or erosion rates from 10Be and 26Al measurements. Quat. Geochronol. 2008, 3, 174-195. [CrossRef]

60. Borchers, B.; Marrero, S.; Balco, G.; Caffee, M.; Goehring, B.; Lifton, N.; Nishiizumi, K.; Phillips, F.; Schaefer, J.; Stone, J. Geological calibration of spallation production rates in the CRONUS-Earth project. Quat. Geochronol. 2016, 31, 188-198. [CrossRef]

61. Lal, D. Cosmic ray labeling of erosion surfaces: In situ nuclide production rates and erosion models. Earth Planet. Sci. Lett. 1991, 104, 424-439. [CrossRef]

62. Stone, J.O. Air pressure and cosmogenic isotope production. J. Geophys. Res. Solid Earth 2000, 105, 753-759. [CrossRef]

63. Chmeleff, J.; von Blanckenburg, F.; Kossert, K.; Jakob, D. Determination of the10Be half-life by multicollector ICP-MS and liquid scintillation counting. Nucl. Instrum. Methods Phys. Res. Sect. B: Beam Interact. Mater. At. 2010, 268, 192-199. [CrossRef]

64. Korschinek, G.; Bergmaier, A.; Faestermann, T.; Gerstmann, U.C.; Knie, K.; Rugel, G.; Wallner, A.; Dillmann, I.; Dollinger, G.; von Gostomski, C.L.; et al. A new value for the half-life of 10Be by Heavy-Ion Elastic Recoil Detection and liquid scintillation counting. Nucl. Instrum. Methods Phys. Res. Sect. B Beam Interact. Mater. At. 2010, 268, 187-191. [CrossRef]

65. Norris, T.L.; Gancarz, A.J.; Rokop, D.J.; Thomas, K.W. Half-Life of 26Al. J. Geophys. Res. 1983, 88, B331-B333. [CrossRef] 
66. Nishiizumi, K. Preparation of 26Al AMS standards. Nucl. Instrum. Methods Phys. Res. Sect. B Beam Interact. Mater. At. 2004, 223-224, 388-392. [CrossRef]

67. Braucher, R.; Merchel, S.; Borgomano, J.; Bourlès, D.L. Production of cosmogenic radionuclides at great depth: A multi element approach. Earth Planet. Sci. Lett. 2011, 309, 1-9. [CrossRef]

68. Braucher, R.; Bourlès, D.; Merchel, S.; Vidal Romani, J.; Fernadez-Mosquera, D.; Marti, K.; Léanni, L.; Chauvet, F.; Arnold, M.; Aumaître, G.; et al. Determination of muon attenuation lengths in depth profiles from in situ produced cosmogenic nuclides. Nucl. Instruments Methods Phys. Res. Sect. B Beam Interact. with Mater. Atoms 2013, 294, 484-490. [CrossRef]

69. Margreth, A.; Gosse, J.C.; Dyke, A.S. Quantification of subaerial and episodic subglacial erosion rates on high latitude upland plateaus: Cumberland Peninsula, Baffin Island, Arctic Canada. Quat. Sci. Rev. 2016, 133, 108-129. [CrossRef]

70. Lifton, N.; Sato, T.; Dunai, T.J. Scaling in situ cosmogenic nuclide production rates using analytical approximations to atmospheric cosmic-ray fluxes. Earth Planet. Sci. Lett. 2014, 386, 149-160. [CrossRef]

71. swisstopo. Tektonische Karte der Schweiz 1:500,000; Bundesamt für Landestopographie, Swisstopo: Wabern, Switzerland, 2005.

72. Pfiffner, A.O. Geologie der Alpen; 2. Auflage; Haupt Verlag: Bern, Switzerland, 2010; ISBN 978-3-8252-8416-9.

73. Weissert, H.; Stössel, I. Der Ozean im Gebirge: Eine geologische Zeitreise durch die Schweiz; 2. Auflage; VDF Hochschulverlag AG an der ETH Zürich: Zurich, Switzerland, 2010.

74. Pavoni, N. Geologie der Zürcher Molasse zwischen Albiskamm und Pfannenstiel. Vierteljahresschr. Nat. Ges. Zürich 1957, 102, 119-315.

75. Matter, A. Sedimentologische Untersuchungen im östlichen Napfgebiet. Ecol. Geol. Helv. 1964. [CrossRef]

76. Sartori, M.; Gouffon, Y.; Marthaler, M. Harmonisation et définition des unités lithostratigraphiques briançonnaises dans les nappes penniques du Valais. Eclogae Geol. Helv. 2006, 99, 363-407. [CrossRef]

77. Reichelt, G. Zur Frage einer Rissvereisung des Südschwarzwaldes. Erdkunde 1960, 14, 53-58. [CrossRef]

78. Pfannenstiel, M.; Rahm, G. Die Vergletscherung des Wehratales und der Wiesetäler während der Rißeiszeit. Ber. Naturf. Ges. Freibg. 1964, 54, 209-278.

79. Leser, H. Zur Glazialproblematik auf Blatt Freiburg-Süd der Geomorphologischen Karte 1: 100000 der Bundesrepublik Deutschland (GMK 100, Blatt 2). Eiszeitalt. Ggw. 1987, 37, 139-144. [CrossRef]

80. Schreiner, A. Zur Quartärgeologie des unteren Wehratals und zur Frage der Vergletscherung des Dinkelberges in der Rißeiszeit (SW Deutschland). EEG Quat. Sci. J. 1995, 45, 62-74. [CrossRef]

81. Suter, H.H. Zur Petrographie des Grundgebirges von Laufenburg und Umgebung (Südschwarzwald). Ph.D. Thesis, University of Zurich, Zurich, Switzerland, 1924.

82. Schlüchter, C. Geologische Untersuchungen im Quartär des Aaretals südlich von Bern. Beiträge zur Geol. Karte der Schweiz; Bundesamt für Landestopographie, Swisstopo: Wabern, Switzerland, 1976; Volume 148.

83. Anselmetti, F.S.; Drescher-Schneider, R.; Furrer, H.; Graf, H.R.; Lowick, S.E.; Preusser, F.; Riedi, M.A. A 180,000 years sedimentation history of a perialpine overdeepened glacial trough (Wehntal, N-Switzerland). Swiss J. Geosci. 2010, 103, 345-361. [CrossRef]

84. Dehnert, A.; Lowick, S.E.; Preusser, F.; Anselmetti, F.S.; Drescher-Schneider, R.; Graf, H.R.; Heller, F.; Horstmeyer, H.; Kemna, H.A.; Nowaczyk, N.R.; et al. Evolution of an overdeepened trough in the northern Alpine Foreland at Niederweningen, Switzerland. Quat. Sci. Rev. 2012, 34, 127-145. [CrossRef]

85. Büchi, M.W.; Graf, H.R.; Haldimann, P.; Lowick, S.E.; Anselmetti, F.S. Multiple Quaternary erosion and infill cycles in overdeepened basins of the northern Alpine foreland. Swiss J. Geosci. 2018, 111, 133-167. [CrossRef]

86. Büchi, M.W.; Lowick, S.E.; Anselmetti, F.S. Luminescence dating of glaciolacustrine silt in overdeepened basin fills beyond the last interglacial. Quat. Geochronol. 2017, 37, 55-67. [CrossRef]

87. Müller, D.; Preusser, F.; Büchi, M.W.; Gegg, L.; Deplazes, G. Luminescence properties and dating of glacial to periglacial sediments from northern Switzerland. Geochronology 2020, 2, 305-323. [CrossRef]

88. Lowick, S.E.; Büchi, M.W.; Gaar, D.; Graf, H.R.; Preusser, F. Luminescence dating of Middle Pleistocene proglacial deposits from northern Switzerland: Methodological aspects and stratigraphical conclusions. Boreas 2015, 44, 459-482. [CrossRef]

89. Klasen, N.; Fiebig, M.; Preusser, F. Applying luminescence methodology to key sites of Alpine glaciations in Southern Germany. Quat. Int. 2016, 420, 249-258. [CrossRef]

90. Rhodes, E.J. Optically stimulated luminescence dating of sediments over the past 200,000 years. Annu. Rev. Earth Planet. Sci. 2011, 39, 461-488. [CrossRef]

91. Chapot, M.S.; Roberts, H.M.; Duller, G.A.T.; Lai, Z.P. A comparison of natural- and laboratory-generated dose response curves for quartz optically stimulated luminescence signals from Chinese Loess. Radiat. Meas. 2012, 47, 1045-1052. [CrossRef]

92. Wallinga, J.; Cunningham, A.C. Encyclopedia of Scientific Dating Methods. Encycl. Sci. Dating Methods 2015, 1-9. [CrossRef]

93. Rentzel, P.; Preusser, F.; Pümpin, C.; Wolf, J.J. Loess and palaeosols on the High Terrace at Sierentz (France), and implications for the chronology of terrace formation in the Upper Rhine Graben. Swiss J. Geosci. 2009, 102, 387-401. [CrossRef]

94. Claude, A.; Akçar, N.; Ivy-Ochs, S.; Schlunegger, F.; Rentzel, P.; Pümpin, C.; Tikhomirov, D.; Kubik, P.W.; Vockenhuber, C.; Dehnert, A.; et al. Chronology of Quaternary terrace deposits at the locality Hohle Gasse (Pratteln, NW Switzerland). Swiss J. Geosci. 2017, 110, 793-809. [CrossRef]

95. Klasen, N. Lumineszenzdatierung Glazifluvialer Sedimente im Nördlichen Alpenvorland (“Luminescence Dating of Glaciofluvial Sediments in the Northern Alpine Foreland”). Ph.D. Thesis, Universität zu Köln, Köln, Germany, 2008. 
96. Preusser, F.; Büschelberger, M.; Kemna, H.A.; Miocic, J.; Mueller, D.; May, J.-H. Exploring possible links between Quaternary aggradation in the Upper Rhine Graben and the glaciation history of northern Switzerland. Int. J. Earth Sci. 2021. [CrossRef]

97. Graf, A.; Akçar, N.; Ivy-Ochs, S.; Strasky, S.; Kubik, P.W.; Christl, M.; Burkhard, M.; Wieler, R.; Schlüchter, C. Multiple advances of Alpine glaciers into the Jura Mountains in the Northwestern Switzerland. Swiss J. Geosci. 2015, 108, 225-238. [CrossRef]

98. Schielein, P.; Schellmann, G.; Lomax, J.; Preusser, F.; Fiebig, M. Chronostratigraphy of the Hochterrassen in the lower Lech Valley (Northern Alpine Foreland). EEG Quat. Sci. J. 2015, 64, 15-28. [CrossRef]

99. Bickel, L.; Lüthgens, C.; Lomax, J.; Fiebig, M. Luminescence dating of glaciofluvial deposits linked to the penultimate glaciation in the Eastern Alps. Quat. Int. 2015, 357, 110-124. [CrossRef]

100. Bickel, L.; Lüthgens, C.; Lomax, J.; Fiebig, M. The timing of the penultimate glaciation in the northern Alpine Foreland: New insights from luminescence dating. Proc. Geol. Assoc. 2015, 126, 536-550. [CrossRef]

101. Monegato, G.; Lowick, S.E.; Ravazzi, C.; Banino, R.; Donegana, M.; Preusser, F. Middle to Late Pleistocene palaeoenvironmental evolution of the southeastern Alpine Valeriano Creek succession (northeastern Italy). J. Quat. Sci. 2010, 25, 617-632. [CrossRef]

102. Monegato, G.; Poli, M.E. The Pleistocene activity of the eastern Southalpine chain unravelled by the terraced staircase of the Meduna valley (NE Italy). Rend. Online Soc. Geol. Ital. 2013, 29, 108-111.

103. Gianotti, F.; Forno, M.G.; Ivy-Ochs, S.; Monegato, G.; Pini, R.; Ravazzi, C. Stratigraphy of the Ivrea Morainic Amphitheatre (NW ITALY): An updated synthesis. Alp. Mediterr. Quat. 2015, 28, 29-58.

104. Buoncristiani, J.F.; Campy, M. Quaternary glaciations in the French Alps and Jura. In Developments in Quaternary Science; Elsevier Inc.: Amsterdam, The Netherlands, 2011; Volume 15, pp. 117-126. ISBN 9780444534477.

105. Maslin, M.A.; Ridgwell, A.J. Mid-Pleistocene revolution and the 'eccentricity myth'. Geol. Soc. Lond. Spec. Publ. 2005, 247, 19-34. [CrossRef]

106. Ehlers, J.; Gibbard, P.L. The extent and chronology of Cenozoic Global Glaciation. Quat. Int. 2007, 164-165, 6-20. [CrossRef]

107. Eissmann, L. Quaternary geology of eastern Germany (Saxony, Saxon-Anhalt, South Brandenburg, Thüringia), type area of the Elsterian and Saalian Stages in Europe. Quat. Sci. Rev. 2002, 21, 1275-1346. [CrossRef]

108. Lauer, T.; Weiss, M. Timing of the Saalian- and Elsterian glacial cycles and the implications for Middle-Pleistocene hominin presence in central Europe. Sci. Rep. 2018, 8, 1-13. [CrossRef]

109. Roskosch, J.; Winsemann, J.; Polom, U.; Brandes, C.; Tsukamoto, S.; Weitkamp, A.; Bartholomäus, W.A.; Henningsen, D.; Frechen, M. Luminescence dating of ice-marginal deposits in northern Germany: Evidence for repeated glaciations during the Middle Pleistocene (MIS 12 to MIS 6). Boreas 2015, 44, 103-126. [CrossRef]

110. Laban, C.; van der Meer, J.J.M. Pleistocene glaciation in the Netherlands. In Developments in Quaternary Science; Elsevier Inc.: Amsterdam, The Netherlands, 2011; pp. 247-260. Volume 15, ISBN 9780444534477.

111. Hughes, P.D.; Gibbard, P.L. Global glacier dynamics during 100 ka Pleistocene glacial cycles. Quat. Res. 2018, 90, 222-243. [CrossRef]

112. Preusser, F.; Reitner, J.M.; Schlüchter, C. Distribution, geometry, age and origin of overdeepened valleys and basins in the Alps and their foreland. Swiss J. Geosci. 2010, 103, 407-426. [CrossRef]

113. Pawley, S.M.; Bailey, R.M.; Rose, J.; Moorlock, B.S.P.; Hamblin, R.J.O.; Booth, S.J.; Lee, J.R. Age limits on Middle Pleistocene glacial sediments from OSL dating, north Norfolk, UK. Quat. Sci. Rev. 2008, 27, 1363-1377. [CrossRef]

114. Pawley, S.M.; Toms, P.; Armitage, S.J.; Rose, J. Quartz luminescence dating of Anglian Stage (MIS 12) fluvial sediments: Comparison of SAR age estimates to the terrace chronology of the Middle Thames valley, UK. Quat. Geochronol. 2010, 5, 569-582. [CrossRef]

115. Astakhov, V. Ice Margins of Northern Russia revisited. In Developments in Quaternary Science; Elsevier Inc.: Amsterdam, The Netherlands, 2011; Volume 15, pp. 323-336. ISBN 9780444534477.

116. Velichko, A.A.; Faustova, M.A.; Pisareva, V.V.; Gribchenko, Y.U.N.; Sudakova, N.G.; Lavrentiev, N.V. Glaciations of the East European Plain: Distribution and Chronology. Dev. Quat. Sci. 2011, 15, 337-359. [CrossRef]

117. Woodward, J.C.; Hughes, P.D. Glaciation in Greece. A new record of cold stage environments in the Mediterranean. In Developments in Quaternary Sciences; Elsevier Inc.: Amsterdam, The Netherlands, 2011; Volume 15, pp. 175-198. ISBN 9780444534477.

118. Hughes, P.D.; Woodward, J.C. Quaternary glaciation in the Mediterranean mountains: A new synthesis. Geol. Soc. Spec. Publ. 2017, 433, 1-23. [CrossRef]

119. Hughes, P.D.; Woodward, J.C.; Gibbard, P.L.; Macklin, M.G.; Gilmour, M.A.; Smith, G.R. The glacial history of the Pindus Mountains, Greece. J. Geol. 2006, 114, 413-434. [CrossRef]

120. Hughes, P.D.; Woodward, J.C.; van Calsteren, P.C.; Thomas, L.E. The glacial history of the Dinaric Alps, Montenegro. Quat. Sci. Rev. 2011, 30, 3393-3412. [CrossRef]

121. Duk-Rodkin, A.; Barendregt, R.W.; Froese, D.G.; Weber, F.; Enkin, R.; Rod Smith, I.; Zazula, G.D.; Waters, P.; Klassen, R. Timing and extent of Plio-Pleistocene glaciations in north-western Canada and east-central Alaska. In Quaternary Glaciations-Extent and Chronology, Part II.; Ehlers, J., Gibbard, P.L., Eds.; Elsevier B.V.: Amsterdam, The Netherlands, 2004; Volume 2, pp. 313-345. ISBN 9780444515926.

122. Rovey, C.W.; Siemens, M. Age constraints of the Middle Pleistocene till and loess sequence in northeast Missouri, USA, based on pedostratigraphy within a polygenetic paleosol. Catena 2021, 203, 105294. [CrossRef]

123. Zhou, S.; Li, J.; Zhao, J.; Wang, J.; Zheng, J. Quaternary Glaciations: Extent and Chronology in China. In Developments in Quaternary Science; Elsevier Inc.: Amsterdam, The Netherlands, 2011; Volume 15, pp. 981-1002. ISBN 9780444534477. 
124. Zhou, S.; Wang, X.; Wang, J.; Xu, L. A preliminary study on timing of the oldest Pleistocene glaciation in Qinghai-Tibetan Plateau. Quat. Int. 2006, 154-155, 44-51. [CrossRef]

125. Xu, L.; Zhou, S. Quaternary glaciations recorded by glacial and fluvial landforms in the Shaluli Mountains, Southeastern Tibetan Plateau. Geomorphology 2009, 103, 268-275. [CrossRef] 